\title{
Nutraceutical Compounds as Sensitizers for Cancer Treatment in Radiation Therapy
}

\author{
Marco Calvaruso ${ }^{\dagger}\left(\mathbb{D}\right.$, Gaia Pucci ${ }^{\dagger}$, Rosa Musso, Valentina Bravatà * ${ }^{(1)}$, Francesco P. Cammarata ${ }^{\circ}$, \\ Giorgio Russo®, Giusi I. Forte $₫$ and Luigi Minafra
}

Istituto di Bioimmagini e Fisiologia Molecolare-Consiglio Nazionale delle Ricerche (IBFM-CNR), 90015 Cefalù (PA), Italy; marco.calvaruso@ibfm.cnr.it (M.C.); gaia.pucci@ibfm.cnr.it (G.P.); rosa.musso@ibfm.cnr.it (R.M.); francesco.cammarata@ibfm.cnr.it (F.P.C.); giorgio.russo@ibfm.cnr.it (G.R.); giusi.forte@ibfm.cnr.it (G.I.F.); luigi.minafra@ibfm.cnr.it (L.M.)

* Correspondence: valentina.bravata@ibfm.cnr.it

t These authors contributed equally to this work.

Received: 25 September 2019; Accepted: 22 October 2019; Published: 23 October 2019

\begin{abstract}
The improvement of diagnostic techniques and the efficacy of new therapies in clinical practice have allowed cancer patients to reach a higher chance to be cured together with a better quality of life. However, tumors still represent the second leading cause of death worldwide. On the contrary, chemotherapy and radiotherapy (RT) still lack treatment plans which take into account the biological features of tumors and depend on this for their response to treatment. Tumor cells' response to RT is strictly-connected to their radiosensitivity, namely, their ability to resist and to overcome cell damage induced by ionizing radiation (IR). For this reason, radiobiological research is focusing on the ability of chemical compounds to radiosensitize cancer cells so to make them more responsive to IR. In recent years, the interests of researchers have been focused on natural compounds that show antitumoral effects with limited collateral issues. Moreover, nutraceuticals are easy to recover and are thus less expensive. On these bases, several scientific projects have aimed to test also their ability to induce tumor radiosensitization both in vitro and in vivo. The goal of this review is to describe what is known about the role of nutraceuticals in radiotherapy, their use and their potential application.
\end{abstract}

Keywords: nutraceuticals; radiotherapy; cancer

\section{Introduction}

Despite the relentless development of new and more effective therapeutic strategies in cancer care, improving clinical approaches aimed to personalize anticancer treatments, still represents a primary goal of our time.

The multifaceted nature and variety of tumors, refractoriness to standard chemotherapy, together with their side effects are the first issue of this challenge, nonetheless, the improvement of targeted treatments, which take into account not only of the specific tumor subtype, but also of the genomic features of the patient to be treated.

The so-called tailored therapies include surgery, chemotherapy, immunotherapy and radiotherapy (RT).

While conventional drug treatments often display detrimental effects also on the normal tissue, the principal purpose behind conventional radiation therapy is to deliver a controlled dose of radiation to a defined tumor bulk and to directly hit cancer cells using high- or low-energy photon beams, thus limiting collateral effects to the surrounding irradiated normal tissue area. In contrast to chemotherapy, which has seen a never-ending development of brand new drugs, the concept of RT has remained the same in over a hundred years and advances have mainly affected the technology used in this clinical 
field [1]. In fact, by the support of imaging techniques coupled with RT, the dose can be delivered more precisely to its target. However, treatment plans always remain the same for each class of tumors not taking into account the molecular profile which characterizes each one of them and that plays instead a pivotal role for the response to RT [2]. Nowadays, several types of neoplasms are treated employing RT and they include breast, ovarian, head and neck, lung, prostate cancers and lymphomas [3].

In recent years, researchers have focused their interest on the mechanisms underlying tumor cell death induced by radiation which is principally caused by the occurrence of genomic damage.

The DNA damage caused by radiation may be direct (through the interaction with the matter in living cells, in particular with the DNA molecules) or indirect (through the production of free radicals generated by water radiolysis). The formation of reactive oxygen species (ROS) as a result of RT is probably the most critical aspect of RT. On one hand, ROS plays a central role in damaging cancer cell DNA leading them to death, on the other hand, it has harmful effects on normal cells. In fact, ROS are normally produced during cell metabolism and a fine-tuned scavenge system is adopted by cells to reduce physiological ROS concentration and their detrimental effects. However, the damage entity of ROS depends on several factors, such as the linear energy transfer (LET) value, the dose and dose rate used during irradiation and on the intrinsic radiosensitivity of the target tissue.

We refer to radiosensitivity as the vulnerability of cells to the detrimental effects of ionizing radiation (IR) and it is commonly accepted that cells with a high proliferate rate (such tumor cells) are more prone to IR damage [1]. Cell radiosensitivity is of paramount importance to achieve a biological effect on the irradiated tumor, and it is different among tissues and can make the difference between a responsive target and an unresponsive target. On this purpose, radiosensitization plays an important role as a neoadjuvant for RT and chemical compounds able to sensitize cancer cells have become a useful tool to improve the efficacy of treatments. Synthetic sensitizers are commonly used as adjuvant in the clinical practice and they can summarily classified in "hypoxic" and "non-hypoxic" sensitizer basing on their ability to restore the physiological levels of intratumoral $\mathrm{O}_{2}$, which levels are notoriously decreased within the tumor bulk. In fact, based on the "oxygen fixation hypothesis", oxygen can permanently stabilize the radical-induced DNA damage caused by radiation [4]. Thus, the oxygen enhancement effect or ratio (OER), given by the ratio between "radiation dose in hypoxia/radiation dose in air", describes the IR effects dependent on the presence of oxygen. Nitroimidazoles such as metronidazole, misonidazole, etanidazole and nimorazole are the most common hypoxic sensitizer. In the absence of oxygen, the reduction of the nitro group of nitroimidazoles reacts with DNA radicals caused by IR, stabilizing them as it happens for the "oxygen fixation hypothesis". These stabilized-adducts lead to DNA strand breaks, thus producing effects on target hypoxic cells $[5,6]$. However, the neurotoxicity of nitroimidazoles limits their use in clinical practice Also, hyperbaric oxygen is used in association with RT and has shown an enhanced radiosensitization. Halogenated pyrimidines such as bromodeoxyuridine (BrdU) and nucleoside analogs (Bleomycin, doxorubicin, etc.) are instead used as non-hypoxic sensitizers as they interfere with DNA repair thus enhancing DNA breaks caused by radiation therapy [7].

If RT is responsible to have a direct effect on cancer bulk, it elicits, on the other hand, an immunogenic cell death (ICD). ICD is triggered after the release and expression, within the tumor-microenvironment, of tumor-derived bioactive molecules that lead to the activation of resident dendritic cells (DCs) and their further cross-priming of CD8+ T cells which play a pivotal role in tumor eradication [8]. DCs are the most representative group of cells included in the class of antigen-presenting-cells (APCs). APCs are key mediators of tumor surveillance and tumor-killing since they process tumor-associated-antigens (TAAs) and in turn present them to immune effector cells to activate them. For this reason, DCs role can be exploited to increase the efficiency of RT by boosting resident DCs activity with the local administration of immunostimulatory adjuvants [9] or by combining RT with DCs vaccination to improve RT effects [10].

In recent years, the attention of researchers has been focused on the use of natural molecules as a coadjuvant of cancer therapy. Nutraceuticals can easily be recovered and they are less expensive 
when compared to synthesized drugs. Moreover, their use minimizes all the collateral effects that, together with the side effects of chemotherapy, exacerbate the already poor quality of life of oncological patients. A thorough analysis of nutraceuticals has been performed in regards to their positive effect in association with chemotherapy, however, few data are known about their role as radiosensitizers. For this reason, this review aims to report the literature state of the art of in vitro, preclinical and clinical use of some nutraceuticals in association to RT and to describe how they affect cancer cell sensitivity to IR.

\section{Curcumin}

Diferuloylmethane, better known as curcumin, is the major component of a flowering plant belonging to the ginger family, the Curcuma longa or turmeric. Originally grown in the Asian continent, Curcumin is nowadays used worldwide as a spice to give food a specific flavor and color. Due to its antioxidant and anti-inflammatory properties, it has been used for centuries also as a natural drug by traditional Chinese medicine [11]. Curcumin is a well-tolerated compound, both in vitro and in vivo models used in several scientific studies that report the effects of curcumin on inhibiting cancer cell survival and proliferation. As an example, the MCF-7 breast cancer cell line treated with increasing doses of curcumin [12]. Moreover, curcumin has displayed a general anticancer activity in a wide spectrum of tumors, thus representing a reliable compound not only for treatment in combination with chemotherapy but especially for cancer prevention [13].

Since its capabilities to induce apoptosis and to inhibit cancer cell growth, researchers have sought to determine the ability of Curcumin to radiosensitize target tumor cells. Thus, the literature reports some papers that analyze the effects mediated by Curcumin in several tumor settings.

After exposure to X-ray irradiation (5 Gy), in human immortalized prostate adenocarcinoma cells PC-3) the expression of TNF- $\alpha$ which in turn activates NF $\kappa B$ and Bcl-2 driven anti-apoptotic signals, is induced. Treatment of PC-3 cells with $2 \mu \mathrm{M}$ Curcumin before irradiation led to the downregulation of radiation-induced $B c l-2$ expression, cytochrome $c$ release, caspases activation and a block in G2/M cell cycle phase [14]. Thus, Curcumin can radiosensitize prostate cancer cells. Together with prostate cancer, Curcumin mediates the radiosensitization of colorectal cancer cells. Indeed, similarly to PC-3 cells, HCT116 and HT29 human colorectal cancer cell lines treated with Curcumin at a concentration of $25 \mu \mathrm{M}$ before a single dose of X-ray radiation (10 Gy) showed an enhanced radiosensitivity due to the suppression of both $N F \kappa B$ activity and $N F \kappa B$-dependent anti-apoptotic (IAP2, Bcl-2, Bcl-XL), inflammatory (COX-2), proliferative (cyclin D1) and angiogenic (VEGF) target genes the expression of $N F \kappa B$ target genes [15]. The use of Curcumin has been tested also for glioblastoma multiforme, a highly aggressive malignant glioma for which fractionated RT ( $60 \mathrm{~Gy} / 30$ fractions) is the standard treatment in association with the co-administration of temozolomide. However, the high rate of recurrence is due to radioresistance mechanisms.

In human glioblastoma U87 cell line, the treatment with Curcumin enhanced the effects induced by $3 \mathrm{~Gy}$ of $\mathrm{X}$-ray in a dose-dependent manner ranging from 5 to $10 \mu \mathrm{M}$, including: reduction of cell viability; arrest of cell cycle in G2/M phase (which is the most sensitive step to radiation); inhibition of two master regulators of tumor progression, the Map Kinases ERK and JNK, through the activation of DUSP-2 which acts as ERK and JNK phosphatase [16].

An interesting study about the effect of Curcumin as a radiosensitizer was evaluated by our research group in the human non-tumorigenic breast epithelial MCF10A cell line and the human breast adenocarcinoma MCF7 and MDA-MB-231 cell lines. These cells were subjected to combined treatment using 4 doses of X-rays (2, 4, 6 and $9 \mathrm{~Gy})$ and 3 concentrations $(2.5,5$ and $10 \mu \mathrm{M})$ of free Curcumin (Free-Cur) or Curcumin loaded solid nanoparticles (Cur-SLN). Dose/response curves and dose modifying factor (DMF) values highlighted an increasing radiosensitization effect in a concentration-dependent manner for both the two drugs; MCF7 cells resulted more sensitive to the combined treatment, reaching a DMF value of 1.78 using $10 \mu \mathrm{M}$ Cur-SLN, while the MDA-MB-231 cells showed to be more sensitive to free-Cur, although a DMF value of 1.38 was obtained with 
the same concentration of the compound. Trancriptomic and metabolomics approach, with the lowest dose/concentration combination $(2 \mathrm{~Gy} / 2.5 \mu \mathrm{M})$, revealed a double action of Curcumin, as an anti-oxidant, with a protective role against IR, and as an antitumor compound, given its ability to stimulate autophagy [17].

Encouraging results were also reached for head and neck squamous carcinoma (HNSCC) using both in vitro and in vivo models. In fact, through the regulation of COX-2 and EGFR crosstalk, Curcumin was able to inhibit EGFR phosphorylation and, in turn, to decrease the activation of mitogen-activated protein (MAP) kinase, which leads to COX-2 expression. This effect was shown in in vitro studies, using the human HNSCC cell line and also in an orthotopic mice model of HNSCC, which were irradiated with a single dose of photon (2-4 Gy) after administration of $15 \mu \mathrm{M}$ of Curcumin. Moreover, a mouse model of head and neck tumor originated by the injection of HNSCC cells into the middle of the mouse tongue, showed a reduction in both tumor weight and size in tumor-bearing mice treated with the combined regimen of Curcumin and irradiation (respectively $15 \mu \mathrm{M}$ and $4 \mathrm{~Gy}$ ) in respect to untreated samples [18].

\section{Resveratrol}

Resveratrol (RV) is a phytoalexin, a natural polyphenol, found in many plants or fruit that are commonly consumed by humans. Its production by plants has the role of protecting them from mechanical injury and the attack of harmful microorganisms such as bacteria and fungi. Beneficial effects deriving from the consumption of RV have been deeply investigated in the last decades after a study conducted in 1992 by Renaud and De Lorgeril also known as the "French Paradox". The study demonstrated that the moderate consumption of red wine (which is rich in resveratrol) is associated with protective effects against coronary heart disease [19].

Since then, together with cardioprotection, anti-aging effects and cancer prevention of resveratrol have been also described [20,21]. All these effects taken together can appear contradictory, in fact, while cardioprotection or aging are easily reducible to an "anti-oxidant" property, the anticancer one is more reliant on "pro-oxidant" features. This is easily explained with the concept of hormesis, according to which the same compound can have opposite activities that are strongly dependent on the administered dose, mentioning the Swiss physician Paracelsus, "The dose makes the poison" and so is the case of resveratrol which exhibits a dual activity depending on its concentration [22,23].

The anticancer activity of resveratrol has been proven as it negatively regulates many mechanisms including cell growth and cell division (e.g., specifically targeting the EGF/EGF-R pathway) and mediates cell cycle arrest and apoptosis (through the induction of $C D K$-inhibitors and the regulation of p53 activation) [24]. In light of its anticancer activity, researchers used resveratrol to test if it plays a role in the radiosensitization of cancer cells as well. Melanoma is the most aggressive type of skin cancer and it is characterized by its high resistance to chemotherapy especially in a metastatic phase. RT has a limited role in the care of melanoma, however, radiation treatment can be used as adjuvant of surgery and chemotherapy to control metastatic spread. In this setting, the combination of $5 \mathrm{~Gy} \gamma$-irradiation with $50 \mu \mathrm{M}$ of resveratrol was able to induce, both in murine cell line SW1 and human cell line WM35, a remarkable reduction of the cell survival fraction by clonogenic assays [25]. Resveratrol treatment at $20 \mu \mathrm{M}$ enhances the effects of IR with doses of $\gamma$-rays between 0 and $8 \mathrm{~Gy}$ also in non-small cell lung cancer (NSCLC). In contrast to melanoma, radiosensitization may be induced in NSCLC cells through an apoptosis-independent mechanism and it is caused by an increase of ROS generation and DNA double-strand breaks production, which leads to accelerated senescence and cell death [26]. Similarly, to Curcumin, RV has been tested in the SU-2 glioblastoma multiforme cell line treated with X-rays. Interestingly, SU-2 cells pretreated with $75 \mu \mathrm{M}$ RV and irradiated with doses of X-ray between 0 and $6 \mathrm{~Gy})$ showed a lower proliferation rate compared to cells treated with irradiation alone and a reduction of stemness which is responsible for self-renewal of cancer cells. In addition, an increased expression of LC3-II which plays a pivotal role in autophagy and a reduction of the anti-apoptotic protein Bcl-2 also in a nude mouse model were observed [27]. In another in vitro model of glioblastoma multiforme, 
such as the U87 MG cell line, the use of RV showed to inhibit the Hypoxia-inducible factor HIF-1 $\alpha$. The activation of HIF-1 $\alpha$ in the tumor context is responsible for reducing both the effect of RT and the uptake of pyrimidine analogs commonly used as chemotherapy agents to kill tumor dividing cells. The combined treatment of U87 cells with $20 \mu \mathrm{M}$ of RV and $1 \mu \mathrm{M}$ of iododeoxyuridine (IUdR), and the following irradiation with $2 \mathrm{~Gy}$ of $\gamma$-rays, induced a decrease in the ability to form cancer cell colonies in vitro and an increase of DNA damage in spheroid cell culture in respect to cells treated with IUdr alone, thanks to the radiosensitizing action of RV [28].

In HNSCC cancers, the over-expression of the signal transducer and activator of transcription 3 (STAT3) promoted growth and survival. The phosphorylated form of STAT3, moreover, up-regulated the activity of anti-apoptotic proteins, down-regulated the tumor suppressor P53 and gave radioresistance and chemoresistance to the tumor. Surprisingly, in HNSCC FaDu cell line, RV almost abolished the phosphorylation of STAT3 through the activation of SOCS-1 (a negative regulator of STAT3), suppressed cell proliferation, induced apoptosis and at concentration of $100 \mu \mathrm{M}$ it was able to radiosensitize cells irradiated with a 10 Gy dose of photon beam [29].

Despite RT can be considered as a first-line treatment for localized prostate cancer, prostate tumors can become refractory to it. Among the factors responsible for the acquisition of radioresistance, the loss of DOC-12/DAB2 interactive protein (DAB2IP) has been reported. Through the inactivation of the PI3K-AKT pathway, DAB2IP is involved in the regulation of cell proliferation, survival and apoptosis. To restore radiosensitivity, $L A P C 4-K D$ and $P C 3-K D$ radioresistant human prostate cancer cell lines (DAB2IP-deficient) were irradiated with X-rays (2-6 Gy) after treatment with 25 or $500 \mu \mathrm{g} / \mathrm{mL}$ of RV, respectively, and the peanut stem extract (PSE) of Arachis hypogaea, which contains a high amount of RV. The administration of both RV and PSE was able to enhance the effects of IR by inhibiting cell proliferation, by inducing apoptosis through cell cycle arrest and by enhancing and prolonging the kinetics of the IR-induced DNA damage response (DDR), that is lower in DAB2IP-deficient tumors. Similar results were reached in a xenograft mouse model of prostate cancer in which the combination of IR with RV and/or PSE (total dose $12 \mathrm{~Gy}, 5$ or $250 \mathrm{mg} / \mathrm{kg}$ respectively) dramatically inhibited tumor growth [30].

Radioresistance is a distinctive feature also of nasopharyngeal carcinomas (NPC). NPCs are more diffused in the Asiatic continent and they are often diagnosed in an advanced and metastatic stage. In order to overcome resistance to IR, RV was used as a pre-treatment (25-150 $\mu \mathrm{M})$ to X-rays irradiation (0-6 Gy) in the human NPC CNE-1 cell line. Consistently with the data obtained in other cancers, it was found that in NPC-cells RV induced radiosensitization reducing cell viability and colony formation in a dose-dependent manner. In this case, the radiosensitizing activity of RV relied on the inhibition of the phosphorylated form of AKT by downregulating E2F1. Moreover, the administration of resveratrol in xenograft tumor mice models of NPC, with $50 \mathrm{mg} / \mathrm{kg} /$ day and irradiated (4 Gy/day) for consecutive 3 days, significantly reduced tumor volume and weight of mice treated compared to the once treated with IR or RV alone [31].

Recently, the radiosensitive effects of RV have been investigated also in breast cancer. In the MCF-7 human breast cancer cell line, the combinatorial effects of RV, used at the concentration of 0,10 , 30 and $100 \mu \mathrm{M}$, together with photon radiation with doses of 1, 2 and $3 \mathrm{~Gy}$, triggered cytotoxic effects, decreased cell proliferation and a cell cycle arrest in the S phase. Surprisingly, such effects were not dependent on the dose of RV used but rather were obtained with the intermediate concentration of $10 \mu \mathrm{M}$ and $3 \mathrm{~Gy}$ irradiation [32].

Summarizing, the administration of chronic and high doses of RV proved to be well tolerated in humans [33], underling its role as a promising adjuvant agent in cancer care.

\section{Withaferin A}

Withaferin A (WA) is a steroidal lactone, a member of a large group of naturally occurring steroids called Withanolides. WA is the first withanolide to be isolated and it was originally obtained in the late 
fifties as an extract from the leaves of the Indian plant Withania Somnifera also known as Ashwagandha or Winter Cherry.

Investigations about the antitumoral effects of WA started immediately after its isolation and they proved the growth inhibitory effect of WA on nasopharyngeal carcinoma and osteosarcoma cells [34,35]. Since then, a plethora of studies showed both the in vitro and in vivo benefits of WA as a natural anticancer agent [36].

In 1996, the radiosensitizing effect in vitro of WA in the V79 Chinese hamster lung fibroblast cell line, a cellular model widely used in studies of DNA damage and DNA repair, was reported. In this study, cells were treated with increasing doses of WA $(2.1,5.25$ and $10.5 \mu \mathrm{M})$ for $1 \mathrm{~h}$ and then irradiated with doses from 1 to $8 \mathrm{~Gy}$ of $\gamma$-rays. WA showed to be well tolerated by cells, the $\mathrm{LD}_{50}$ of the drug was $16 \mu \mathrm{M}$. At the lowest concentration of $2.1 \mu \mathrm{M}$ WA did not affect cell viability, however, it was able to mediate a potent cell-killing effect induced by $\gamma$-irradiation at a dose of 2 Gy [37]. In the same year, withaferin A was also tested in vivo in the ascitic form of a murine model of mammary carcinoma, Ehrlich ascites carcinoma (EAC). Mice of 6-8 weeks of age were injected intraperitoneally with $10^{6}$ tumor cells, and $24 \mathrm{~h}$ after the injection, they were treated with WA alone or in combination with RT to verify the tumor growth inhibition. To establish the influence of tumor size on the anticancer effects of WA, tumors were allowed to grow up until 10 days before injection with WA. Withaferin A was used at different dose fractions of 5 or $7.5 \mathrm{mg} / \mathrm{kg} \times 8$ days after tumor injection, $10 \mathrm{mg} / \mathrm{kg} \times$ 5 days, 20 or $30 \mathrm{mg} / \mathrm{kg} \times 2$ days with or without $\gamma$-rays (7.5 Gy). As expected, the administration of WA coupled with a single dose of RT showed tumor growth inhibition and increased the tumor free-survival and the median survival time (MST) of animals. Specifically, mice treated with $5 \mathrm{mg} / \mathrm{kg} \times$ 8 days produced $40 \%$ of tumor-free survival, such percentage increased gradually with the increasing of the dose reaching the $100 \%$ of free-tumor survivals and a median survival time of 120 days (a time comparable to 5 years in human) with the maximum dose of $30 \mathrm{mg} / \mathrm{kg} \times 2$ days. Similar results were obtained also when WA was administered 5, 7 or 10 days after tumor inoculation, demonstrating that WA can partially overcome the influence of tumor growth. However, at advanced tumor stages, treatment with WA and RT was ineffective. Overall, also in mice, WA was well tolerated and the treatment with RT alone could induce few beneficial results [38]. The in vivo response to $\gamma$-irradiation of transplantable mouse fibrosarcoma was investigated. Mice were treated with progressive doses of WA from 10 to $60 \mathrm{mg} / \mathrm{kg}$ before a single dose irradiation of $30 \mathrm{~Gy}$ and multiple parameters of tumor response were evaluated: The volume doubling time (VDT), defined as the number of days in which the untreated tumor doubles its volume in respect to the treated one; growth delay (GD), the time required by the untreated tumor to reach five times the treated volume; complete remission accounting for total regression and no recidivism within 120 days; partial regression and no response. Fibrosarcomas treated with WA and followed by radiation exhibited a dose-dependent linear increase both in VDT and GD: the increase became significant when the dose was greater than $20 \mathrm{mg} / \mathrm{kg}$, reaching the best efficacy at the concentration of $40 \mathrm{mg} / \mathrm{kg}$. Nevertheless, mice treated with WA in the dose range between 40 and $60 \mathrm{mg} / \mathrm{kg}$ showed also a compelling complete remission in $55 \%$ and partial remission in $45 \%$ of cases [39]. The same experimental conditions (doses from 10 to $60 \mathrm{mg} / \mathrm{kg}$ of WA and a single dose of 30 Gy of $\gamma$-irradiation) were used to study the effects of WA + RT in fibrosarcoma and to study the effects on melanoma. As expected, the results were roughly identical [40].

In the late years, the attention on the radiosensitizing effects of withaferin A has also been aimed to highlight the pathways which are compromised after WA treatment. Based on the in vitro evidence that WA decreased the viability of the U937 human histiocytic lymphoma cell-line [41], it was investigated if WA could increase the effects of IR in the same cell line model. U937 cells were treated with different concentrations of WA $(0,0.3,0.5$ and $1 \mu \mathrm{M})$ in association with increasing doses of X-rays (from 0 to $10 \mathrm{~Gy})$. However, most of the experiments were conducted combining the subtoxic dose of $0.5 \mu \mathrm{M}$ and 10 Gy of irradiation because, at that condition, WA together with IR can effectively induce almost $40 \%$ of cell death and also all the peculiar morphological changes of apoptosis such as cell shrinkage, cytoplasm aggregation and nuclear condensation. Additionally, in respect to the other experimental 
settings (WA or IR alone), administration of WA followed by IR lead to: Increased levels of ROS production, an increased expression of cleaved PARP, down-regulation of $B c l-2$, the activation of JNK and $p 38$ signaling pathways which are known to be activated by many cellular stresses such as ROS [42]. Almost identical effects observed in the U937 cell line, were obtained by the same group of research in other cell lines, including Caki (renal carcinoma), SK-Hep1 (liver cancer), MDA-MB-231 (breast cancer) and HeLa (cervical cancer) cells exposed to 10 Gy of X-rays after treatment with $4 \mu \mathrm{M}$ of Withaferin A [43].

\section{Celastrol}

Celastrol or Tripterine, a pentacyclic triterpenoid isolated from the root of the "thunder god vine" (Tripterygium wilfordii), is well-known for its anti-inflammatory properties and commonly used in Chinese traditional medicine as a remedy for several pathologies. The discovery of its proteasome inhibitory activity and its antimetastatic capacity elected celastrol as a good candidate for further investigations in the field of cancer biology [44].

The evidence of a chemical compound with related antitumor effects often leads scientists to test it also as a radiosensitizer, that is the case also of Celastrol whose radiosensitizing potential was evaluated both in vitro and in vivo in the PC-3 human prostate cancer cell line. PC-3 cells were treated with two different concentrations of Celastrol $(0.2$ and $0.4 \mu \mathrm{M}$ for $1 \mathrm{~h}$ before irradiation) and with different doses of X-rays (from 0 to $6 \mathrm{~Gy}$ ). At the dose of $0.4 \mu \mathrm{M}$ but not 0.2 it was found that Celastrol significantly enhanced IR-induced cell cytotoxicity and clonogenic cell killing in a dose-dependent manner. Radio-enhancement is often linked to the interference with the radiation-induced DNA damage repair pathways. On these bases, immunofluorescence and western blotting analyses were used to follow the kinetics of appearance and disappearance of one of the markers activated after radiation-induced DNA damage, the phosphorylated form of the histone $\mathrm{H} 2 \mathrm{AX}(\gamma H 2 A X)$. The analysis showed that PC-3 cells, treated with celastrol in combination with IR, were positive for $\gamma H 2 A X$ for a longer time in respect of cells only irradiated, thus demonstrating that celastrol hampers DNA double-strand break repair. Nevertheless, markers of apoptosis (including cleaved PARP and caspase-3 activation) were more expressed in cells that underwent combined treatment with celastrol and IR than in cells treated only with X-rays. To test the effects of Celastrol and IR in vivo, a PC-3 xenograft was created in athymic NCr-nu/nu mice. Mice were inoculated with PC-3 cells and when tumors reached $100 \mathrm{~mm}^{3}$, they were treated with $1 \mathrm{mg} / \mathrm{kg}$ of celastrol ( 5 days/week for 3 weeks) $1 \mathrm{~h}$ before irradiation with a single dose of 2 Gy ( 5 days/week for 2 weeks). Celastrol showed to be well tolerated and in association with IR, it was able to delay the tumor doubling time compared to IR alone. Moreover, as proved by histological examination, the association of celastrol and radiation therapy significantly improved apoptosis and decreased the formation of new blood vessels (angiogenesis) [45].

Celastrol $(0.5 \mu \mathrm{M})$ administration was combined with $\gamma$-irradiation (range from 1 to $4 \mathrm{~Gy}$ ) in the NCI-H460 human lung cancer cell line. As expected, cell growth and survival were affected according to the radiation dose delivered, thus the expression of targets involved in radiation sensitivity, such as EGFR, ErbB2, Survivin and Akt, were investigated after Celastrol treatment. Except for $A k t$, all the other markers were significantly decreased together with a Celastrol-dependent inhibition of HSP90 and the consequent destabilization of its client proteins (for example EGFR) [46]. Moreover, the radiosensitizing effect of Celastrol on lung cancer cells was proved to be reliant on its quinone methide moiety which enhanced the ROS production after IR [47].

Lastly, the widest analysis to identify potential candidates able to sensitize human lung cancer cell lines, such as A549 and H460, to IR was in silico conducted and through the use of the bioinformatic connectivity map tool, Celastrol was identified as one of the most effective drugs among 30 drugs tested. Based on these preliminary results, the A549 and H460 cell lines were treated with Celastrol $2 \mu \mathrm{M}, 4 \mathrm{~h}$ before irradiation with a 6-MV photon beam at different doses (2-10 Gy). Since a clonogenic assay showed that treatment with Celastrol plus IR decreased the survival of both cell lines, the in vivo response to IR after Celastrol administration was evaluated. A preclinical lung tumor model was 
created injecting the A549 cell line in mice which underwent a combined therapy with Celastrol ( $2 \mathrm{mg} / \mathrm{kg} / 5$ day) and IR (10 Gy) for 12 days. Respectively at days 6 and 12, mice were sacrificed and tumors were analyzed using H\&E staining. The efficacy of the treatment was assessed by measuring the mean percentage of the tumor necrotic fraction which correlates with tumor cell death. The assay showed that tumors treated with the combined regimen had larger intratumoral necrotic areas with respect to the ones belonging to groups of mice treated with Celastrol or IR alone [48].

\section{Ursolic Acid}

Ursolic Acid (UA) (also called urson, prunol or malol) belongs, as with the abovementioned Celastrol, to the family of the pentacyclic triterpenoids. It is found in the peel of many fruits such as apples, blueberries and prunes, as well as in many herbs like rosemary and thyme. Despite having been used unconsciously as a beneficial substance for centuries in traditional medicine, the increasing interest in the health effects of natural molecules has recently lead to the description of the pharmacological properties of UA which exerts anticancer, anti-inflammatory and anti-microbial activities [49]. Recently, its radiosensitization activity has also been underlined. In the DU145 human prostate cancer cell line, the treatment with $30 \mu \mathrm{M}$ of UA for $24 \mathrm{~h}$ before $\gamma$-irradiation ( $5 \mathrm{~Gy}$ ), showed a significant reduction in cell viability respect to untreated cells. The effect was associated with a reduction of cellular volume and condensed or fragmented nuclei, caspase-3 activation, increasing levels of cleaved PARP and DNA fragmentation, typical signatures of apoptosis. The decrease of cell viability, the activation of the apoptotic cascade and an increasing level of ROS generation were shown also in CT26 human colon carcinoma and B16F10 mouse melanoma cells, both treated in the same condition of DU145 cells. Moreover, mice implanted with B16F10 cells and treated with $100 \mathrm{mg} / \mathrm{kg}$ and 4 Gy IR for 2 weeks, underwent an inhibition of tumor growth caused by a down-regulation of Bcl-2 and Survivin, proved by western blot analysis of the tumor tissue [50].

Treatment with UA caused a differential effect after exposure of normal or cancer cells to UV. In particular, the human CRL-4000 hTERT-RPE (retinal pigment epithelium used as a control) cell line and the CRL-11147 skin melanoma cells were both treated with $1 \mu \mathrm{g} / \mathrm{mL}$ of UA for at least $8 \mathrm{~h}$ before UV irradiation for $5 / 10 \mathrm{~min}$ in order to evaluate the differential UVR-mediated ROS production, cell cycle arrest and cell death. Surprisingly, UA regulated oppositely the UVR-induced oxidative stress in control cells and melanoma cells. In fact, at the same experimental conditions, the DHE assay used to measure the levels of intranuclear superoxide demonstrated an increase in DHE oxidation occurring in cancer cells respect to its oxidized state in control cells, suggesting that UA can act as a photo protector for normal cells and as a photosensitizer for tumors. The cell cycle analysis of irradiated cells showed a cytostatic effect of UA in skin melanoma cells that were enriched in their G1-phase population to the detriment of the S-phase one. Besides, treatment with UA was able to specifically potentiate optical radiation-induced apoptosis and cell death in skin melanoma cells and not in RPE cells, as tested by clonogenic assay and by expression of the apoptotic marker YO-PRO-1 [51].

Radiosensitizing effects of UA were also highlighted in the BGC-823 human gastric adenocarcinoma cell line. A gastric adenocarcinoma is an aggressive form of cancer for which surgery still represents the best frontline approach, however, often patients are diagnosed in advanced stages and cannot undergo surgery. For those cases with unresectable locally advanced neoplasms, RT is the main alternative to surgery. To determine the radiosensitizing effects of UA, a clonogenic survival assay was performed on the BGC-823 cells treated with UA in the concentration of $0,6.25$ and $10 \mu \mathrm{g} / \mathrm{mL}$ for $24 \mathrm{~h}$ and then exposed to increasing doses of $0,2,4,6$ and 8 Gy of electron beam radiation. The combination of RT and UA significantly decreased the survival fraction indicating that UA enhanced RT effects in a dose-dependent manner. Compared to cells irradiated or treated with UA only, the combination of $10 \mu \mathrm{g} / \mathrm{mL}$ of UA plus 2 Gy IR showed to induce the arrest of cell cycle in the G1 and G2/M phases and to increase the number of apoptotic cells (positive to Annexin $V$ and PI). Moreover, cells treated with UA and RT exhibited higher levels of ROS production (detected by the analysis of DCF-DA mean fluorescent intensity) and a lower percentage of Ki-67 positive proliferating cells [52]. 
An interesting study about the effect of UA as a radiosensitizer was carried out on a radioresistant cell line of NSCLC obtained by transfection with a recombinant plasmid expressing a mutant form of HIF- $1 \alpha$, the H1299/M-hypoxia-inducible factor- $1 \alpha$. Experiments were performed treating NSCLC cells with 50 or $80 \mu \mathrm{M} / 1$ for $24 \mathrm{~h}$ before 2 Gy of X-ray irradiation, the cell lines H1229 and H1229 transfected with an empty plasmid were used as a comparison. Intriguingly, results showed that when irradiated after pretreatment with UA, NSCLC cells and especially HIF-1 $\alpha$-expressing cells were more sensitive to irradiation respect to the other cell lines. Such sensitization was correlated also with increasing levels of DNA damage assessed by the analysis of the formation of micronuclei, remarkable diminished levels of endogenous glutathione (considered as one of the most important scavengers of ROS), increasing ROS production and a marked inhibition of HIF-1 $\alpha$ protein levels [53].

\section{Zerumbone}

Zerumbone (2,6,10-Cy-cloundecatrien-1-one, 2,6,9,9-tetramethyl-,[E,E,E]-) (ZER), a monocyclic sesquiterpene compound, is a cytotoxic component isolated from rhizomes of Zingiber zerumbet Smith $[54,55]$. According to its phytomedical properties, it has been used since ancient times as a condiment in food and herbal medicine in eastern countries [56]. It has been also shown to have anti-inflammatory, anti-proliferative and antitumor properties in several tumor types, such as breast, pancreas, colon, lung and skin [57-59]. Moreover, in the last years, some studies revealed that Zerumbone plays a sensitizing effect on tumors after treatment with IR [60], being involved in the regulation of DNA DSBs' repair induced by IR and in the regulation of cell cycle and apoptotic pathway [61].

As regards radiosensitizing effects of Zerumbone, some researchers described that the combined treatment with ZER $(10 \mu \mathrm{g} / \mathrm{mL}$ ) and $\gamma$-rays irradiation (range of 5-10 Gy) increased the radiation-induced and the heat shock protein (HSP)-mediated cell death in the NCI-H1299 lung adenocarcinoma cell line 48-72 $\mathrm{h}$ after irradiation. In addition, ZER enhanced the cleavage of Caspase 3 and PARP. Furthermore, the same combined treatment, used in in vivo nude mice models after grafting of NCI-H460 and NCI-H1299 non-small cell lung cancer (NSCLC) cells, inhibited the binding of HSP27 to apoptotic molecules such as Cytochrome c or PKC [60].

In the U87 MG and U373 MG human glioblastoma cell lines, pretreatment with ZER followed by progressive doses (range of 0-4 Gy) of X-rays induced inhibition of Gli-1 expression, that usually correlates with metastasis and tumor relapse. In particular, it has been seen that D0 (radiation dose with $37 \%$ survival) values, for both cell lines, were lower when treated with zerumbone compared to the control (U87 MG: 3.4 Gy vs. 4.3 Gy; U373 MG 2.6 Gy vs. 4.1 Gy) [62].

In addition, pre-treatment of PC3 and DU145 human prostate cancer cells with ZER $(10 \mu \mathrm{M})$ before administration of different doses of IR (0-6 Gy) decreased cell survival, abrogated the expression of $\gamma-H 2 A X$ and reduced the expression of phosphorylated ATM, JAK2 and STAT3 proteins, all of them involved in the DNA damage repair pathway [63].

In the HCT116 and HT29 colon-rectal cancer cell-lines, different concentrations of ZER $(5,10$, $25 \mu \mathrm{mol} / \mathrm{L})$ were added $4 \mathrm{~h}$ before and $3 \mathrm{~h}$ after $\gamma$-rays irradiation $(2,4,6 \mathrm{~Gy})$. In particular, treatment with 10 and $25 \mu \mathrm{mol} / \mathrm{L}$, radiosensitized both cell lines inducing apoptosis and enhancing the radiation-induced G2/M arrest at 2 and $4 \mathrm{~Gy}$. The evaluation of $\gamma-H 2 A X$ foci showed that their number remained higher until $24 \mathrm{~h}$ post IR treatment. Furthermore, in both cell lines, pre-treatment with ZER decreased the radiation-induced expression of two proteins involved in DSBs repair, $\mathrm{p} A T M^{\mathrm{Ser} 1981}$ and DNA-PKCs, and it depleted the levels of intracellular Glutathione (GSH) [64].

\section{Caffeic Acid Phenethyl Ester}

Caffeic acid phenethyl ester (CAPE) is an active component of honeybee propolis, a phenolic compound and a structural derivative of flavonoids [65]. It has antiviral, bactericidal, anti-inflammatory and antioxidant properties, and it has been proved to be more toxic for cancer cells than normal ones [66]. In particular, CAPE can change the redox state by perturbing the activation of GSH and 
inducing apoptosis in transformed cells. It has been also reported that CAPE could potentiate the effect of RT in several types of cancer [67].

It was shown that CAPE might enhance radiation-induced cell cycle arrest or apoptosis in medulloblastoma cells. In the human medulloblastoma Daoy cell line, the combined treatment with CAPE $(3,10,30 \mu \mathrm{M})$ and IR (2 Gy), showed an enhancement in ROS production and significant inhibition of NF- $k B$ activity. Also, levels of apoptosis and DNA fragmentation increased, with a parallel down-regulation of Cyclin B1 protein expression [68].

In the same cell line, other researchers described that pretreatment with CAPE $(0.1-10 \mu \mathrm{M})$ for $24 \mathrm{~h}$ before exposition to $\gamma$-rays irradiation at various doses $(0,2,4,6,8 \mathrm{~Gy})$, induced a reduction of the cell survival fraction in a concentration-dependent manner, with SF values of 100, 88.5, 56.1, 24.7 and $0 \%$, respectively. Moreover, these data showed that CAPE inhibited cell-cycle progression by arresting cells in the S-phase [69].

The radiosensitizing effect of CAPE was also shown in mouse CT26 adenocarcinoma cells, both in vitro and in vivo. In CT26 cells, pretreatment with CAPE $(2 \mu \mathrm{g} / \mathrm{mL})$ before X-rays irradiation $(2,4,6$ and $8 \mathrm{~Gy}$ ) decreased the cell survival rate and reduced the NF- $k B$ activation. Also, in mice bearing CT26 tumor cells, pretreatment with $10 \mathrm{mg} / \mathrm{kg}$ CAPE followed by IR (10 Gy), induced a marked inhibition of tumor growth and volume [70].

X-rays irradiation with doses of 2, 4, 6, 8 Gy) on the MDA-MB-231 and T47D breast cancer cell lines, after treatment with CAPE $(1 \mu \mathrm{M})$ for $72 \mathrm{~h}$, decreased both survival rate of MDA-MB-231 (at 6 and 8 Gy) and T47D (at 2 and 4 Gy) cells. In particular, this combined treatment delayed the DNA repair process for up to $60 \mathrm{~min}$ after exposure. In addition, by the comet assay, it was shown that the \% DNA in tail, directly proportional to DNA damage, reverted almost to the control value (8.9) $120 \mathrm{~min}$ after exposure on the MDA-MB-231 cells, but remained higher (14.9) for up to $120 \mathrm{~min}$ on the T47D cells [71].

Finally, the use of CAPE was tested also in the human A549 lung cancer cell line. Treatment with CAPE at various concentrations $(0,2,4$ and $6 \mu \mathrm{g} / \mathrm{mL})$ for $1 \mathrm{~h}$, combined with different doses $(0,2,4$, 6 and $8 \mathrm{~Gy})$ of X-rays irradiation, were associated with a reduction in the cell survival rate, mostly observed at higher doses of CAPE and IR [72].

\section{Emodin}

Emodin (6-methyl-1,3,8-trihydroxyanthraquinone) is a natural phenolic compound extracted from the roots and rhizome of several plants, such as the traditional Chinese herbs Rheum palmatum, Polygonum cuspidatum and Cascara buckthorn [73,74]. Emodin shares a similar molecular structure with DMNQ (2,3-dimethoxy-1,4-naphthoquinone) and mitochondrial ubiquinone, and it could be qualified as endogenous ROS generators because of its property of transferring electrons [75]. It has antibacterial, antiviral, anti-inflammatory and anticancer effects $[76,77]$. Emodin's mechanism of action in inhibiting the development of cancer remains barely elucidated, but its antitumor action has been observed in leukemia, breast cancer, colon cancer, lung cancer, etc. [78], also in association with RT.

It has been proved that exposure of CNE-1 NPC human nasopharyngeal carcinoma cell line to Emodin under hypoxic conditions enhanced their radiosensitivity. In particular, treatment with 3.9 and $7.8 \mu \mathrm{g} / \mathrm{mL}$ of emodin, $24 \mathrm{~h}$ before irradiation with $2 \mathrm{~Gy}$ IR, caused an increase in the apoptosis ratio $(\%)$, with a value of 25-21, and the arrest of the cell cycle in G2/M phase. Furthermore, under hypoxic conditions, this combined treatment leads to an increase in the relative content of ROS (161-149\%) and to a decreased expression of HIF-1 $\alpha$ mRNA and protein. Furthermore, in vivo experiments on CNE-1 xenograft model showed that combined treatment with Emodin and 2 Gy IR caused a tumor growth delay of 6.90 and 9.15 days, for low $(4 \mathrm{mg} / \mathrm{kg})$ and high dose of Emodin $(12 \mathrm{mg} / \mathrm{kg})$, respectively [79].

Interesting results in other cancer cell lines were also found. In HeLa cervical cancer cell line, treatment with different concentrations of Aloe Emodin (AE) $(0,50,100$ and $200 \mu \mathrm{M})$ before the exposition to different doses of $\mathrm{X}$-rays irradiation (0, 2, 4, 6, 8 and $10 \mathrm{~Gy})$, induced an alteration of some radiobiological parameters of the dose survival curve. In particular, there was a decrease in the 
mean lethal dose (D0), in the quasi-threshold dose (Dq), in the extrapolation number $(\mathrm{N})$ and the daily fraction dose of 2 Gy in clinical practice (SF2), and an increase in the sensitizing enhancement ratio SER(D0) and SERDq in a concentration-dependent manner. The analysis of cell cycle distribution and apoptosis, after treatment with $50 \mu \mathrm{M} \mathrm{AE}$ and $4 \mathrm{~Gy} \mathrm{IR}$, showed an increase in the number of cells in the G2/M phase and a sub-G1 peak at 24, 48 and $72 \mathrm{~h}$. In addition, this combined treatment increased the expression of cyclin $B, \gamma-H 2 A X$ and ALP activity [80].

The combined treatment with $\gamma$-rays $(10 \mathrm{~Gy})$ and $\mathrm{AE}(10 \mu \mathrm{M})$ induced a significant decrease of growth and viability on the human HepG2 hepatocellular carcinoma cell line, also under hypoxic conditions. This treatment induced a greater increase of both G2/M and apoptotic population, tested by an increase of expression in cleaved PARP-1 levels, a decrease in the expression of $H I F-1 \alpha$ and its target genes, such as JMJD1A and JMJD2B, involved in hypoxia-induced radioresistance [81].

The same experimental approach was carried out using the FSa p53 mutant (Mut) murine sarcoma cell line. Exposure to $50 \mu \mathrm{M}$ AE before irradiation with 2 Gy X-rays increased the nuclear Survivin levels and in the decrease of the nuclear transport protein CRM-1, which is involved in the export of Survivin from the nucleus to the cytoplasm [82].

In the CN1-E nasopharyngeal carcinoma cell line, pretreatment with $10 \mathrm{mg} / \mathrm{L}$ of GXHSWAQ-1 (a synthetic compound created on the basis of the chemical structure of Emodin) for $24 \mathrm{hrs}$ before X-rays irradiation (2 Gy), caused a damage in the integrity of mitochondrial structure, with swelling and/or matrix compartments vacuole formation and a collapse in the transmembrane potential. A proteomic analysis showed that, in the radiosensitized group, Rac1 and CDC42 protein expression, whose decrease correlates with a high invasive potential of cancer cells, were higher, while CDH1 protein expression, usually known as a potent suppressor of radiosensitization, was significantly lower [83].

\section{Flavopiridol}

Flavopiridol is a synthetic flavone derived from Dysoxylum binectariferum, a plant used in Indian medicine [84]. This molecule inhibits the Cdks activities arresting the cell cycle (G1/S or G2/M phases) [85]. The cell cycle arrest was observed in many histotypes of cancer $[86,87]$. This effect on the cell cycle was analyzed and confirmed in several experimental tumor models, such as chronic lymphocytic leukemia, squamous cancer and breast cancer cells. Moreover, it plays an anti-proliferative effect through the transcriptional suppression activity of genes involved in the proliferation pathways [88]. In several models in vitro and in vivo, it was demonstrated that Flavopiridol stimulates apoptosis [87], inhibits angiogenesis [89] and increases the chemotherapeutic effects [90].

A study in vitro and in vivo evaluated radiosensitivity effects of docetaxel and Flavopiridol following the radiation exposure on the lung carcinoma. The H460 human lung carcinoma cell line was treated with this sequence: docetaxel $(10 \mu \mathrm{M}), \gamma$-irradiation $(0-5 \mathrm{~Gy})$ and Flavopiridol $(120 \mu \mathrm{M})$, while $\mathrm{H} 460$ cells were inoculated in nude mice which were treated with docetaxel $(2.5 \mathrm{mg} / \mathrm{kg}), \gamma$-irradiation (2 Gy) and Flavopiridol (1.25 mg/kg). Researchers performed different experiments by testing different treatment combinations and have observed after treatment an increase of radiation effects in vivo and in vitro with an arrest of the cell cycle (G1 and G2/M) [91].

In the esophageal squamous carcinoma, the treatment of three cell lines, such as TE8, TE9 and KE4, with or without Flavopiridol ( $0.05 \mathrm{nmol} / \mathrm{L}$ ) before X-ray irradiation (2-10 Gy) induced a decrease of the levels of cyclin D1, Rb in all cell lines and of Bcl-2 protein in the KE4 cells. The experimental data demonstrated the enhanced radiosensitivity of cell lines and suggested that the use of Flavopiridol at a low dose could represent an efficacy therapeutic approach against the esophageal squamous carcinoma [92].

Besides, the Eca109 esophageal squamous cancer cell line was treated with gradient concentrations of flavopiridol for $48 \mathrm{~h}(0-517.5 \mathrm{nM})$ and X-ray irradiation (0, 2, 4, 6 and $8 \mathrm{~Gy})$. The results highlighted a decrease of the Cyclin D1 expression level, enhancing the percentage of cells in the G2/M phase. 
Moreover, Caspase-3 and Bax proteins increased in Eca109 cells, while Bcl-2 expression decreased. Therefore, the Eca109 cells, treated with Flavopiridol and radiation, showed a more radiosensitivity [93].

The radiosensitizing effect of Flavopiridol was demonstrated in the SEG-1 esophageal adenocarcinoma cells. The in vitro results obtained highlighted that cells treated with Flavopiridol $(300 \mathrm{nM})$ for $24 \mathrm{hrs}$ before or $7 \mathrm{~h}$ after $\gamma$-radiation (2-6 Gy) showed greater radiosensitivity respect to the control [94]. This mechanism is multiple and is characterized by the inhibition of some CDKs, the redistribution of the cell cycle with an accumulation of SEG-1 cells in G1 and G2 phases and induction to apoptosis. Moreover, in the xenograft mouse model, a single dose of Flavopiridol $(15 \mathrm{mg} / \mathrm{kg})$ in combination with $\gamma$-radiation (15 Gy) was sufficient to determine an enhance of the SEG1 tumor tissue response to irradiation. The results showed that the Flavopiridol administration before $(4 \mathrm{~h})$ irradiation is more effective than after $(7 \mathrm{~h})$ [94].

A research group analyzed in glioma and cervical tumor cells the potential involvement of $p 53$ and $B c l-2$ in radio-sensitivity mechanisms, following treatment with Flavopiridol [95]. These proteins are known to be involved in cell cycle regulation, DNA repair and apoptosis. Previous works showed that the difference in the expression levels of $p 53$ and $B c l-2$ proteins can lead to radioresistance phenomena in several cancers $[96,97]$. A172 glioma and HeLa cervical tumor cells were stably transfected with plasmids containing mutated forms of $p 53$ (A172/mp53) and Bcl-2 (HeLa/bcl-2) genes, respectively. Cell lines were treated with Flavopiridol $(0.0125 \mu \mathrm{M}$ for A172 and $0.1 \mu \mathrm{M}$ for HeLa) for $24 \mathrm{hrs}$ after irradiation (2-8 Gy) and cell viability and potential DNA damage were evaluated. The experimental data showed that cells that contained mutated $p 53$ or overexpressed $B c l-2$ were more radioresistant than wild-type, confirming a potential key role of these proteins in the mechanisms of radioresistance. Furthermore, the treatment with Flavopiridol increased the cytotoxic effects of radiations in the transfected cells compared to the untreated ones. It has been hypothesized the presence of a common pathway or targetable molecule would be valuable in order to determine the radiosensitizing effect of Flavopiridol mediated by $p 53$ and Bcl-2. This molecular target could be the RAD51 protein, involved in the regulation of the repair processes following DNA damage due to radiation exposure $[98,99]$. This protein interacts with p53 and is inhibited from the high expression levels of $B c l-2$ [100]. Probably, the Flavopiridol action occurs interfering with the molecular interaction between RAD51, p53 and Bcl-2 and thus in the repair mechanisms. However, this hypothesis needs further clarification. It has been suggested that the use of Flavopiridol as a radiosensitizer molecule could be useful for the treatment of tumors with an altered status of $p 53$ and $B c l-2$ [95].

The radiosensitizing effects of Flavopiridol were evaluated in vivo by inoculation of GL261 glioma cells in murine models. The tumor control/cure dose of radiation assay (TCD50) was performed to measure the dose of $\gamma$-radiation ( $65 \mathrm{~Gy}$ ) required to treat $50 \%$ of local tumors. The combined treatment of $\gamma$-radiation (5 Gy), fractionated for 10 days with the administration of Flavopiridol ( $5 \mathrm{mg} / \mathrm{kg}$ ) in the murine models showed a decrease in cell growth and a greater sensitivity to radiation. Moreover, it has been hypothesized that the anti-angiogenic effect exerted by the Flavopiridol inhibits the HIF-1 pathway and thus the VEGF factor [101] that is closely associated with the radioresistance mechanisms [102].

The OCA-I ovarian carcinoma cells treated with Flavopiridol $(300 \mathrm{nM})$ for $24 \mathrm{~h}$ and $\gamma$-radiations (1-6 Gy) exhibited an increase of the radiosensitivity compared to control. The results showed an expression decrease of $K u 70$ and $K u 86$ proteins involved in the repair mechanisms [103] a redistribution of the cell cycle with a greater accumulation of these cells in phases of cell cycle more radiosensitive, as G1 and G2 [104,105] and an inhibition of cyclin/cdk complexes through the attenuation of the phosphorylated form of $R b$, blocking cell cycle [106]. Moreover, the Flavopiridol could repress gene transcription process through the inhibition of $C d k-9$ that is involved in DNA repair with Cyclin T [107] and $K$ [108] and regulates RNA polymerase II activity through the formation of a cyclin-complex [107]. These results strengthen the use of Flavopiridol as a radio-sensitizing molecule [109].

The cytotoxic effects of Flavopiridol were evaluated on the HeLa human uterine cervix cancer cell line exposed to irradiation with X-rays (0, 2, 5 and $10 \mathrm{~Gy}$,) and treated with Flavopiridol (IC50 $=80 \mathrm{nM}$ ). In particular, it has been observed that a considerable reduction of the cell survival fraction occurred 
by treating the cells for $24 \mathrm{~h}$ after irradiation, while no significant results were observed in cells treated before irradiation or simultaneously [110].

The treatment of the DU145 and PC3 human prostate cancer cell lines with Flavopiridol (60-90 nM) at three different times (1, 6 and $24 \mathrm{~h}$ ) after X-ray irradiation (2 Gy) showed in both cell lines a higher number of $\gamma \mathrm{H} 2 \mathrm{AX}$ foci in cells treated for $24 \mathrm{~h}$ with Flavopiridol and radiation, compared to cells treated with irradiation alone. The increased expression of $\gamma H 2 A X$ could be an index of inhibition of the mechanisms of DNA repair Flavopiridol-mediated [111].

A study performed on the zebrafish model evaluated the Flavopiridol radiosensitizing effect, also verifying if it occurred through the Cyclin D1 inhibition, as previously demonstrated in ovarian cancer cells [109]. The results above confirmed the radiosensitizing role of this molecule. Indeed, the embryos treated with Flavopiridol ( $500 \mathrm{nM}$ ) before irradiation with $\gamma$-rays (10-40 Gy) displayed reduced viability compared to the control and exhibited a morphological alteration of the dorsal tail, due to exposure to radiation. This change appears to be dose-dependent. Moreover, the micro-injection in the embryos of the antisense hydroxylprolyl-phosphono peptide nucleic acid oligomers $(0.5 \mathrm{pmol})$, which down-regulated cyclin $D 1$, and irradiation determined not only a reduction in viability but also the manifestation of the same phenotypic characteristics observed in the embryos flavopiridol-treated. These data are proof of the cyclin D1 involvement in the radiosensitizing mechanism flavopiridol-mediated [112].

\section{Berberine}

Berberine, an alkaloid component extracted from several medicinal herbs, including Huang Lian, is characterized by low toxicity. Therefore, it is widely used as a drug for gastrointestinal discomfort in China and has been tested in clinical trials for type 2 diabetes mellitus $[113,114]$ and on hypercholesterolemia [115]. Research has demonstrated that berberine has an antitumor activity for a wide variety of cancer cells [116-122]. This effect often occurs through inhibition of the cell cycle progression and the promotion of apoptosis. A study showed that Berberine possesses a radiosensitizing feature shown in lung cancer cells [123].

Liu Z. et al. have previously reported that Berberine may inhibit cancer cell proliferation by inducing DNA double-strand breaks in osteosarcoma cells [122]. In a subsequent study, the researchers have demonstrated that Berberine at low concentrations can significantly radiosensitize the esophageal cancer cells (ESCC). The cancer cell lines (KYSE30, KYSE450, KYSE410, EC109 and TE-1) treated with Berberine $(15 \mu \mathrm{M})$ for $24 \mathrm{~h}$ and X-ray irradiation (2-6 Gy) exhibited a major sensibility to the radiation exposure. The experimental data showed that this effect is mediated from the downregulation of RAD51 involved in the repair of DSBs. The overexpression of RAD51, found in human ESCC tissues, suggested the potential use of this protein as a biomarker associated with the radiation response. Moreover, at radiosensitizing concentrations Berberine not determined effects or downregulation of RAD51 in non-malignant cells. Therefore, it is supposed that the radiosensitizing effect of Berberine may be specific to the ESCC cells [124].

Another study evaluated the radiosensitivity effects of berberine on the hypoxic ECSS cell lines (ECA109 and TE13). The ECSS cells in hypoxic conditions were treated with a low concentration of Berberine ( $5 \mu \mathrm{M}$ and $15 \mu \mathrm{M})$ for $24 \mathrm{~h}$ and irradiated with X-rays (1-9 Gy). The hypoxic cells were more radioresistant respect to the growth of the cells in normal conditions, but the treatment with Berberine sensitizes these cells to the radiation exposure. Therefore, the experimental data showed the decrease of the survival fraction of hypoxic cells following the berberine treatment and the inhibition of HIF-1 $\alpha$, associated with the radio-resistance phenomenon [125] and VEGF, a protective factor of the endothelial cells from radiation damage [126]. The in vitro results were confirmed through the inoculation of ECA109 in the nude mice, treated with Berberine $(5 \mathrm{mg} / \mathrm{kg})$ for two days before the X-ray radiation $(8 \mathrm{~Gy})$. The data in vitro and in vivo highlighted that berberine increased the radiosensitivity of ESCC cells and xenografts, and this effect was associated with the inhibition of HIF-1 $\alpha$ and VEGF expression [127]. The same experimental design in vitro and in vivo was applied on the prostate cancer 
cells -LNCaP, DU-145- and the nasopharyngeal carcinoma (NPC) cell lines CNE-1, CNE-2. The same results were observed confirming the importance of the HIF-1 $\alpha$ and VEGF expression in the mechanism of radiosensitivity Berberine-mediated in prostate cancer [128] and NPC [129].

Another human prostate cancer cell line (PC-3) was treated with berberine $(30 \mu \mathrm{M})$ for $24 \mathrm{~h}$ and exposed to $\gamma$-irradiation (4-6 Gy) showed a high apoptotic index. It was supposed that this molecule induced the apoptosis mechanism through the pathway generation of the ROS in prostate cancer. Moreover, the study highlighted that the combined action of Berberine and radiation on the prostate cancer cells determined the deregulated expression of several molecules, involved in the apoptotic process, cell cycle and radio -sensitizing/-resistant mechanisms, such as Bcl-2 [130], $N F-K b$ [131], p53 [132], p38 and JNK [133]. Therefore, the researchers suggested the use of Berberine as a radiosensitizing molecule to enhance the effect of RT [134]. Moreover, it was observed that the CNE-2 cells (NPC), treated with variable doses of Berberine (25-100 $\mu \mathrm{mol} / \mathrm{L})$ for $24 \mathrm{~h}$ and $\gamma$-irradiation (4-8 Gy) were characterized by a decrease of the mRNA and by a down-regulation of the protein expression of $S p 1$, a transcription factor associated to the tumoral migration [135-137] and correlated to the tumoral invasion and radioresistance in NPC patients [138]. This molecular process involved, also, the selective inhibitor of Sp1 (Mithramycin A), which is enhanced in the CNE-2 cells, treated with Berberine and irradiation. These experimental results demonstrated the involvement of Sp1 and Mithramycin A in the radioresistant pathway in NPC and highlight the potential role as therapeutic targets [139].

Finally, the radiosensitizing action of Berberine was evaluated in breast cancer models. The breast cancer cells MCF-7 and MDA-MB468 were treated with berberine $(15 \mu \mathrm{M})$ and exposed to variable doses of X-rays (1-4 Gy). The experimental results showed that the treatment with Berberine determined the cell cycle arrest, the inhibition of the activation of the repair mechanisms of X-ray-induced DSBs, through the evaluation of $\gamma H 2 A X$ foci, and the downregulation of RAD51 [140].

\section{Genistein}

Genistein, a soy isoflavone, inhibits cell proliferation and thus enhances apoptosis by inhibiting the activity of tyrosine protein kinases and DNA topoisomerase II. Moreover, these molecules promote the DNA repair mechanism, performing an anti-angiogenic and antitumor effect $[141,142]$ Several studies have demonstrated that Genistein inhibits in vitro the growth of several cancer cells, including lymphoma, melanoma, neuroblastoma, breast and prostate cancer cells [143]. Experimental results showed that the combined treatment with Genistein $(40 \mu \mathrm{mol} / \mathrm{L})$ and $\gamma$-irradiations (4 Gy) inhibited significantly the cell growth of the cervical cancer cells (Hela) and increased the radiosensitivity through a down-regulation of Survivin, which inhibited caspase 9 and blocked the apoptotic pathway [144]. This inhibitor was absent in normal differentiated tissues, while it was highly expressed in malignant tumors [145]. Clinically, high levels of Survivin have been associated with a reduction in survival and an increase in relapse and resistance to therapy [146,147]. Therefore, it was suggested the use of Genistein to reduce the IR therapeutic dose and the possible adverse reactions correlated to RT [148]. Based on previous studies showing the ability of Genistein to inhibit the growth of cervical tumor cells in vitro [149], Yashar et al. [150] evaluated the possible role of this compound as a radiosensitizer in other epithelial cervical cancer cell lines (CaSki and ME180) with two different spectra of HPV infection. Both cell lines were treated with Genistein $(1-80 \mu \mathrm{M})$ for $48 \mathrm{~h}$ before photons radiation (200, 500 or $800 \mathrm{cGy}$ ). At $40 \mu \mathrm{M}$, less than $5 \%$ of ME180 cells survived all the radiation doses, while an increase in radiosensitization in CaSki cells was seen only at 500 and 800 cGy with all Genistein doses (in a dose-dependent manner). Additional studies showed as Genistein acts as a radiosensitizer blocking cell cycle in G2/M, specifically in ME180 cells, and moreover, in both cell lines, leading to a dose-dependent induction of Cytochrome c by a reduction of $M c l-1$ and total AKT, suggesting an involvement in the apoptotic pathway [150]. Encouraging results in cervical tumor cells were also obtained by other researchers. Combined treatment of different doses of Genistein $(0-200 \mu \mathrm{M})$ and $\gamma$-irradiation (10 Gy) in CaSki and human normal keratinocyte HaCaT cells, showed that the 
pretreatment with Genistein rendered CaSki cells hypersensitive to the death effect of IR, revealing an induction of apoptotic bodies. In particular, it was observed the inhibition of cell proliferation with an accumulation of cells blocked in the G2/M transition, the increase in the expression levels of $p 53$, p21 and Cdc2-tyr-15-p and the decrease of the cyclin B levels. Apoptosis induction was shown to be associated with cytochrome $c$ release, cleavage of caspase-3 and -8, inhibition of the anti-apoptotic Bcl-2 expression and enhancement of pro-apoptotic Bax expression, upregulation of intracellular ROS and downregulation of COX-2 expression and PGE2 production [151].

A study investigated the radiosensitizing effect of Genistein on breast cancer cells with different estrogen receptor (ER) status. Human breast cancer cell lines MCF-7 and MDA-MB-231 were treated with Genistein $(5-20 \mu \mathrm{M})$ and irradiated with X-rays (4 Gy). The experimental data showed the increase of DNA damages, the arrest of the cell cycle at the G2/M phase, through up-regulation of phosphorylation of $A T M, C h k 2, C d c 25 c$ and $C d c 2$, and the enhancement of radiosensitivity through a mitochondria-mediated apoptosis pathway [152].

The radiosensitizing effect of Genistein was tested on the non-small cell lung cancer (NSCLC) cells (A549) and the normal lung fibroblast cells (MRC-5). Cells were treated with Genistein $(10 \mu \mathrm{M})$ for $48 \mathrm{~h}$ and then irradiated with X-rays (4 Gy). The experimental results showed that in A549 cell line the Genistein enhanced the cellular damages from oxidative stress, increasing ROS and decreasing GSH, an antioxidant factor [153]. It was observed that Genestein influenced the DNA methylation status [154,155]: in particular, researchers showed that this treatment involved inhibition of methylation in the promoter region of Keap1, causing an increase in the transcription/translation levels of this gene. This molecular modification led to the inhibition of $N f t 2$, an antioxidant factor [156], and the deregulation of the oxidative system [157]. The result of this process was an increase in the apoptotic levels and a more radiosensitivity of the A549 cells. Furthermore, it is interesting that this mechanism involving the Keap1/Nft2 pathway was opposite in the normal lung fibroblast MRC-5 cells. Therefore, it has been observed that these normal cells treated with Genistein were characterized by an activation of $\mathrm{Nft2}$, which determined a greater synthesis of antioxidant enzymes (such as GSH) and a decrease of the apoptotic rate and the radiosensitivity. These results showed not only the radiosensitizing effect of Genistein, but also the specificity of this effect on the A549 cells compared to MC5 cells [158]. In another study, the NSCLC cells (A549, Calu-1, H1975 and H460) were treated with 30-60 $\mu \mathrm{M}$ of Genistein for $24 \mathrm{~h}$ and exposed to IR (4 Gy). This combined Genistein-IR treatment led to a decrease of the cytoplasmic levels of $B c l-x$, a known anti-apoptotic factor associated with the radioresistance of lung cancer patients, as demonstrated in some works [159]. Furthermore, $B c l-x$ was also involved in the regulation of autophagy through the molecular interaction with the Beclin-1 protein $[160,161]$. Summarizing, the authors suggest that the Genistein has a potential radiosensitizing effect in the NSCLC cells, because able to regulate the Bcl-x cytoplasmic expression level and thus apoptotic and autophagic processes [162].

\section{Selenium}

Selenium (Se) is an essential element for humans, plants and microorganisms, naturally present and mainly diffused in two inorganic forms, selenite (Se4+) and selenate (Se6+), as well as in their organic derivatives. In spite of the other selenium compounds, usually associated with an antioxidant activity, sodium selenite is an oxidizing agent that makes cancer cells more prone to oxidative stress. Several studies showed, indeed, its cytotoxic properties, through direct or indirect activation of natural killer (NK) cells and by inhibiting the disulfide exchange on the surface of cancer cell membranes (phenomenon usually related to the uncontrolled cell division) and inducing changes in the structure of proteins required for cell survival, it makes cancer cells more susceptible to the activity of phagocytic cells and to the apoptotic mechanism $[163,164]$.

The use of selenite, therefore, seems to exhibit promising anticancer effects, as described in numerous studies, also in association with RT. 
Schueller et al. showed as 14 days pre-treatment of $\mathrm{C} 6$ rat glioma cell line with different selenite concentrations (2-3.6 $\mu \mathrm{M})$, before $\gamma$-rays (0-20 Gy), led to a lower plating efficiency, especially for radiation doses $>2 \mathrm{~Gy}$, and to an overall lower survival than the untreated control. In particular, for Se non-toxic concentrations of 0,2 and $3 \mu \mathrm{M}$, respectively, SF2 amounted to $0.72,0.48$ and 0.46 and SF5 to $0.37,0.25$ and 0.12 , with an associated D0 value of $6.1,4.7$ and $3.8 \mathrm{~Gy}$ ) [165].

Other researchers evaluated the effects of selenium, in the vehiculated form of selenium nanoparticles (Nano-Se), as radiosensitizer. Various concentrations of Nano-Se $(0-3 \mu \mathrm{g} / \mathrm{mL})$, for $24 \mathrm{~h}$ of treatment, were used before X-rays ( $0-8 \mathrm{~Gy}$ ) on MCF-7 breast cancer cells, and radiosensitivity was evaluated with different essays. Combined treatment lead to a higher mortality rate than both treatment used alone (IR or Nano-Se), with a reduction in the colony formation rate to 25.27 and 15.97 under 4 Gy IR associated to 0.15 or $0.3 \mu \mathrm{g} / \mathrm{mL}$ Nano-Se, and to 6.81 and 4.06 under 6 Gy IR associated to 0.15 or $0.3 \mu \mathrm{g} / \mathrm{mL}$ Nano-Se, respectively. Combined treatment, furthermore, lead to an acceleration through G1/S phase inducing cell cycle arrest at the G2/M phase, to the activation of autophagy by the increase of $L C 3$ positive structures and to an increase in both endogenous and irradiation-induced ROS formation [166].

The radiosensitizing effect of selenium was also observed in A375 human melanoma cells. In particular, Liua et al. studied the effects of a highly hemocompatible erythrocyte membrane-coated ultrasmall selenium nanosystem combined with bevacizumab (RBCs@Se/Av) (0-15 $\mu \mathrm{M} ; 4 \mathrm{~h}$ ) combined to X-rays (2-8 Gy). Experimental data showed a strong reduction in the survival fraction of A375 cells after combined treatment (17.5\%) compared to X-rays or RBCs@Se/Av alone (56.2\% and 96\%, respectively), and an increase in the Sub-G1 cell proportion, in the levels of activated caspases-3/-8/-9 and PARP cleavage, demonstrating an increase in the caspase-mediated apoptotic pathway. In addition, this treatment leads to an increase in ROS generation, ROS-mediated mitochondrial fragmentation, in the Ser15 phosphorylated $p 53$ form and in the levels of many DNA damage markers, but a reduction in the expression level of VEGF and VEGF2, index of a decrease of tumor angiogenesis [167].

\section{Discussion}

Today is known that the concept that "one size fits for all", is not applicable in cancer care because patients could be erroneously treated using general therapeutic criteria that did not take into account the complex heterogeneity of cancer. Thus, the finding of the right cure for specific neoplasm represents one of the trickiest challenges of science.

Nowadays, thanks to the introduction of sequencing and gene expression profile techniques, we are conscious about the importance of more and more customized therapies, in fact, tumors affecting the same organ can be further classified into subgroups with a specific biological profile that gives them the ability to acquire resistance to those treatments that are instead effective for tumors with similar histological features.

Fortunately, decades of never-ending research in the field of cancer have led to the establishment of more and more effective therapies aimed to personalize medicine in light of the features both of the cancer and the patient to be treated. Clinical approaches such as chemotherapy and RT have been implemented, while the first has been characterized by the discovery of new and more effective drugs, the latter is based on the same basics since the discovery of radioactivity and its first application in cancer treatment which occurred in 1896 [168].

In respect to chemotherapy, RT is able to deliver a certain dose directly to the tumor, limiting damages to the normal tissue. This ability to spare healthy areas surrounding the tumor is more precise when hadron therapy is used. Due to their nature, charged particles such as protons and carbon ions can deposit most of their energy within the target with little diffusion $[169,170]$.

Both conventional RT, which uses photons (gamma or X-rays), and hadron therapy, are capable to induce cell death because they alter the DNA structure of their targets. DNA breaks can be induced in a direct way when the IR impacts with the double-strand helix or can be defined as indirect when caused 
by the effects of ROS production triggered by RT. ROS are not only responsible for DNA damage, but they can also oxidize almost every molecular structure within the cells, causing their death [171].

However, as it often occurs with chemotherapy, cancer can also acquire resistance to RT. Therefore, the administration of radiosensitizing compounds could coadjuvate RT itself. Nowadays, several drugs are used with this purpose and they are commonly referred to as hypoxic and non-hypoxic radiosensitizer (e.g., nitroimidazoles and halogenated pyrimidines) but they yet exhibit collateral systemic effects. The use of nutraceuticals, which may mimic the effect of chemically synthesized radiosensitizer, could help to overcome this issue since they are characterized by low toxicity. Recently, the interest in natural compounds for the treatment of several pathologies has risen, this is not only due to their less detrimental effects but also because of their low economical costs.

The health-promoting effects of compounds coming from nature have been known for thousands of years and their use in medical care still plays a pivotal role in traditional medicines, such as Chinese and Ayurvedic traditional medicine. The beneficial effects of nutraceuticals are exploited in hypertension, diabetes, osteoporosis and lipid control and they have been introduced in clinical practice as neo-adjuvant of chemotherapy [172-174].

On these bases, it is not hard to expect that nutraceuticals play a role also as mediators of radiosensitization. According to the numerous scientific papers describing their anticancer activity, we tried to collect data regarding the most known natural compounds: Curcumin, Resveratrol, Withaferin, Celastrol, Ursolic Acid, Zerumbone, CAPE, Emodin, Flavopiridol, Berberine, Genistein and Selenium, which demonstrate their beneficial effects even as radiosensitizers (Table 1). All the results we analyzed share a unique leitmotif, and apart for few nutraceuticals taken into exams, the best characterized molecular effects involved in radiosensitization of tumors are: The activation of pro-apoptotic signals as demonstrated by their overall ability to induce downregulation of $B C L-2$, increase of PARP and Caspase-3 cleavage; a wide-ranging increase of cells blocked in the G2/M cell cycle phase which is, in fact, the most responsive stage of mitosis to IR; a frequent inhibition of HIF-1 $\alpha$ and VEGF and thus of tumor angiogenesis. Other and less studied pathways induced by nutraceuticals such as cell migration, inflammation, autophagy and ROS production, have been summarized in Figure 1.

Moreover, many of the mechanisms underlying the protective effects of nutraceuticals has not been clarified and are yet to be described. A further and deeper understanding of the key mechanisms involved in radiosensitization driven by nutraceuticals could give a clearer picture of the pathways affected by their activity and would help to identify new targets to increase cell radiosensitization. 
Table 1. The table shows the most relevant and updated works regarding the radiosensitizer effect of the most known natural compounds, cited in this review.

\begin{tabular}{|c|c|c|c|c|}
\hline Nutraceuticals & $\begin{array}{c}\text { Structure and } \\
\text { Molecular Formula }\end{array}$ & Tumor Targets & $\begin{array}{c}\text { Type of } \\
\text { Treatment }\end{array}$ & Bibliography \\
\hline Curcumin & & $\begin{array}{c}\text { Breast cancer, Colonrectal Cancer, } \\
\text { Glioblastoma Multiforme, } \\
\text { Head and Neck squamous Cancer, } \\
\text { Prostate Cancer. }\end{array}$ & X-rays & [14-18] \\
\hline Resveratrol & $C_{1}$ & $\begin{array}{l}\text { Breast Cancer, Glioblastoma, Head } \\
\text { and Neck squamous Cancer, } \\
\text { Melanoma, Nasopharyngeal } \\
\text { Carcinoma, Non-Small Cell Lung } \\
\text { Cancer, Prostate Cancer. }\end{array}$ & $\begin{array}{l}\gamma \text {-rays } \\
X \text {-rays }\end{array}$ & [25-32] \\
\hline Withaferin A & & $\begin{array}{c}\text { Breast Cancer, Cervical Cancer, } \\
\text { Ehrlich Ascites Carcinoma, } \\
\text { Fibrosarcoma, } \\
\text { Histiocytic Human Lymphoma, Liver } \\
\text { Cancer, } \\
\text { Melanoma, Renal Carcinoma. }\end{array}$ & $\begin{array}{l}\gamma \text {-rays } \\
\text { X-rays }\end{array}$ & [37-43] \\
\hline Celastrol & & Lung Cancer, Prostate Cancer. & $\begin{array}{l}\gamma \text {-rays } \\
\text { X-rays }\end{array}$ & {$[45,47,48]$} \\
\hline Ursolic Acid & & $\begin{array}{c}\text { Colon Carcinoma, Gastric } \\
\text { Adenocarcinoma, Melanoma, } \\
\text { Non-Small Cell Lung Cancer, } \\
\text { Prostate Cancer. }\end{array}$ & $\begin{array}{l}\gamma \text {-rays } \\
\chi \text {-rays }\end{array}$ & {$[50-53]$} \\
\hline Zerumbone & & $\begin{array}{l}\text { Colonrectal Cancer, Glioblastoma, } \\
\text { Lung adenocarcinoma, Non-Small } \\
\text { Cell Lung Cancer, Prostate Cancer. }\end{array}$ & $\begin{array}{l}\gamma \text {-rays } \\
\mathrm{X} \text {-rays }\end{array}$ & {$[60,62-64]$} \\
\hline $\begin{array}{l}\text { Caffeic Acid } \\
\text { Phenetyl Ester }\end{array}$ & & $\begin{array}{l}\text { Adenocarcinoma, Breast Cancer, } \\
\text { Lung Cancer, Medulloblastoma. }\end{array}$ & $\begin{array}{l}\gamma \text {-rays } \\
X \text {-rays }\end{array}$ & [68-72] \\
\hline Emodin & & $\begin{array}{c}\text { Cervical Cancer, Hepatocellular } \\
\text { Carcinoma, Nasopharyngeal } \\
\text { Carcinoma, Sarcoma. }\end{array}$ & $\begin{array}{l}\gamma \text {-rays } \\
\mathrm{X} \text {-rays }\end{array}$ & [79-83] \\
\hline Flavopiridol & $C_{-}$ & $\begin{array}{c}\text { Cervix Cancer, Esophageal } \\
\text { adenocarcinoma, Esophageal } \\
\text { squamous Carcinoma, Glioma, Lung } \\
\text { Carcinoma, Ovarian Carcinoma, } \\
\text { Prostate Cancer, Zebrafish Model. }\end{array}$ & $\begin{array}{l}\gamma \text {-rays } \\
\mathrm{X} \text {-rays }\end{array}$ & [91-95,101,109-112]. \\
\hline Berberin & $\mathrm{NO}_{4}$ & $\begin{array}{l}\text { Breast Cancer, Esophageal Carcinoma, } \\
\text { Lung Carcinoma, Nasopharyngeal } \\
\text { Carcinoma, Osteosarcoma, } \\
\text { Prostate Cancer. }\end{array}$ & $\begin{array}{l}\gamma \text {-rays } \\
X \text {-rays }\end{array}$ & {$[122-124,127,128,134,140]$} \\
\hline Genistein & & $\begin{array}{l}\text { Breast Cancer, Cervical Cancer, } \\
\text { Non-Small Cell Lung Cancer. }\end{array}$ & $\begin{array}{l}\gamma \text {-rays } \\
X \text {-rays }\end{array}$ & {$[148,150-152,158,162]$} \\
\hline Sodium Selenite & $\mathrm{C}_{15} \mathrm{H}_{10} \mathrm{O}_{5}$ & Breast Cancer; Glioma; Melanoma. & $\begin{array}{l}\gamma \text {-rays } \\
X \text {-rays }\end{array}$ & [165-167] \\
\hline & $\mathrm{NaSeO}_{3}$ & & & \\
\hline
\end{tabular}




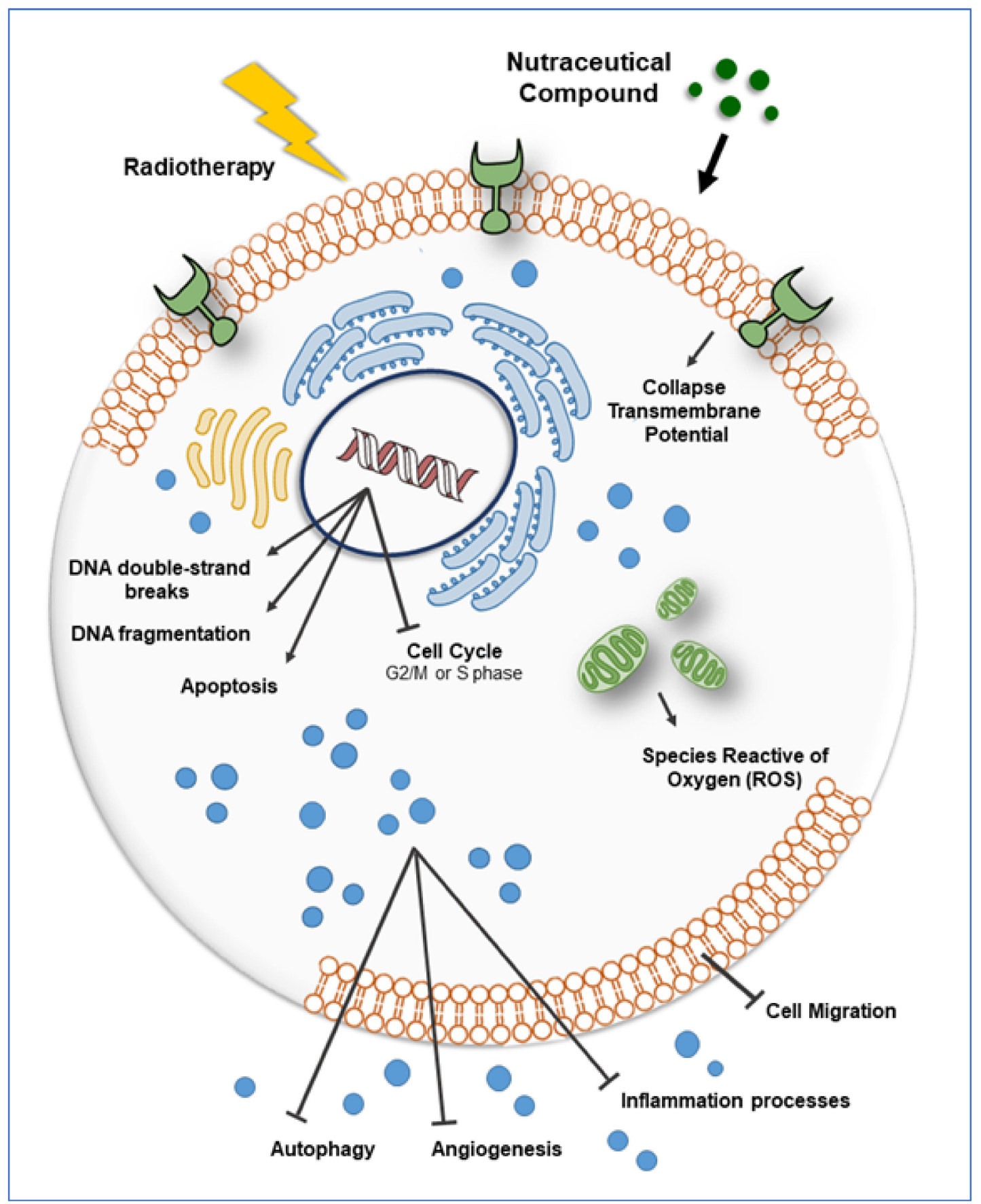

Figure 1. The figure displays how nutraceuticals compounds and radiation treatment could affect cellular pathways involved in migration, inflammation, autophagy and reactive oxygen species (ROS) production.

\section{Conclusions}

Unlike chemotherapy, recently based on the development of new drugs able to interfere with specific tumor targets, RT is less reliant on the biological features of cancer to be treated. As a matter of fact, each cancer (even the ones affecting the same organ) exhibits distinctive characteristics that are tied with a different RT response and degree of relapses after RT. An increase in terms of response to treatment can be reached thanks to the synergistic effects given by the administration of radiosensitizing compounds that have been lately introduced in clinical practice as neoadjuvant for RT. However, synthetic radiosensitizers show collateral effects that exacerbate the ones already caused by RT. For 
this reason, the use of nutraceuticals which can counteract the mechanisms of tumor resistance to RT but still with less collateral effects are the topic of several scientific projects aimed to test their efficacy.

The focus of our review is to propose an overview of the state of the art of the adoption of nutraceuticals as adjuvant in RT (Figure 2) and to give some hints about the potential pathways involved in their activity.

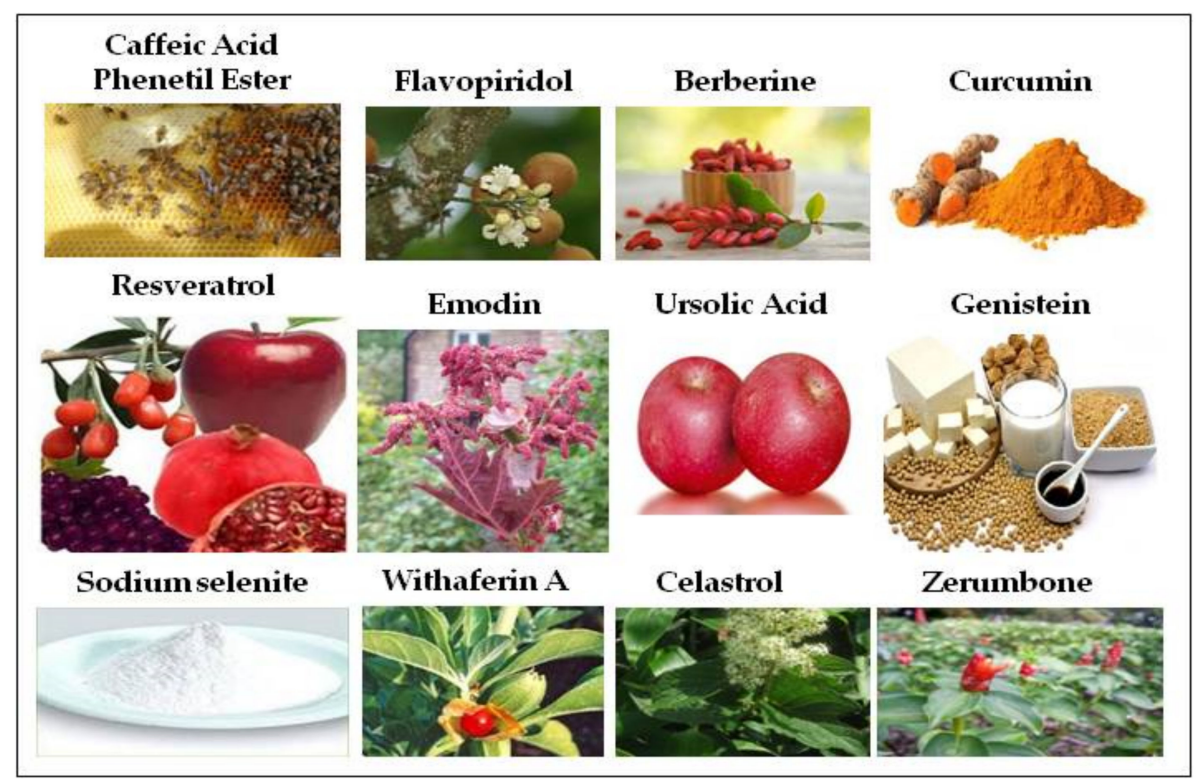

Figure 2. The figure displays the main sources of natural compounds cited in this review.

Author Contributions: All authors participated in the conception, design, interpretation, and elaboration of the findings of the study, as well as in drafting and revising the final version. All authors read and approved the final content of the manuscript.

Funding: This work was supported by GeSeTon project (funded by Italian MISE Grant No. 489 of 21/02/2018) and by "SErvizi di gestione ed accreditamento di LABoratori biomolecolari (SELAB)" project (CUP:G77B17000260009-CIP:2014.IT.05.SFOP.014/3/10.4/9.2.10/0020).

Conflicts of Interest: The authors declare no conflict of interest.

\section{References}

1. Forte, G.I.; Minafra, L.; Bravatà, V.; Cammarata, F.P.; Lamia, D.; Pisciotta, P.; Cirrone, G.A.P.; Cuttone, G.; Gilardi, M.C.; Russo, G.; et al. Radiogenomics: The utility in patient selection. Transl. Cancer Res. 2017, 65, 852-S874. [CrossRef]

2. Bravatà, V.; Cava, C.; Minafra, L.; Cammarata, F.P.; Russo, G.; Gilardi, M.C.; Castiglioni, I.; Forte, G.I. Radiation-Induced Gene Expression Changes in High and Low Grade Breast Cancer Cell Types. Int. J. Mol. Sci. 2018, 19, 1084. [CrossRef] [PubMed]

3. Baskar, R.; Lee, A.; Yeo, R.; Yeoh, W. Cancer and radiation therapy: Current advances and future directions. Int. J. Med. Sci. 2012, 9, 193-199. [CrossRef] [PubMed]

4. Grimes, R.D.; Partridge, M. A mechanistic investigation of the oxygen fixation hypothesis and oxygen enhancement ratio. Biomed. Phys. Eng. Express 2015, 1, 045209. [CrossRef]

5. Rauth, A.M. Pharmacology and toxicology of sensitizers: Mechanism studies. Int. J. Radiat. Oncol. Biol. Phys. 1984, 10, 1293-1300. [CrossRef]

6. Bonnet, M.; Hong, C.R.; Wong, W.W.; Liew, L.P.; Shome, A.; Wang, J.; Gu, Y.; Stevenson, R.J.; Qi, W.; Anderson, R.F.; et al. Next-Generation Hypoxic Cell Radiosensitizers: Nitroimidazole Alkylsulfonamides. J. Med. Chem. 2018, 61(3), 1241-1254. [CrossRef]

7. Iliakis, G.; Kurtzman, S. Application of non-hypoxic cell sensitizers in radiobiology and radiotherapy: Rationale and future prospects. Int. J. Radiat. Oncol. Biol. Phys. 1989, 165, 1235-1241. [CrossRef] 
8. Walle, T.; Martinez Monge, R.; Cerwenka, A.; Ajona, D.; Melero, I.; Lecanda, F. Radiation effects on antitumor immune responses: Current perspectives and challenges. Ther. Adv. Med. Oncol. 2018. [CrossRef]

9. Schölch, S.; Rauber, C.; Tietz, A.; Rahbari, N.N.; Bork, U.; Schmidt, T.; Kahlert, C.; Haberkorn, U.; Tomai, M.A.; Lipson, K.E.; et al. Radiotherapy combined with TLR7/8 activation induces strong immune responses against gastrointestinal tumors. Oncotarget 2015, 6(7), 4663-4676. [CrossRef]

10. Choi, C.W.; Jeong, M.H.; Park, Y.S.; Son, C.H.; Lee, H.R.; Koh, E.K. Combination Treatment of Stereotactic Body Radiation Therapy and Immature Dendritic Cell Vaccination for Augmentation of Local and Systemic Effects. Cancer Res. Treat. 2019, 51(2), 464-473. [CrossRef]

11. Prasad, S.; Aggarwal, B.B. Turmeric, the Golden Spice: From Traditional Medicine to Modern Medicine, 2nd ed.; CRC Press/Taylor \& Francis: Boca Raton, FL, USA, 2011.

12. Khazaei Koohpar, Z.; Entezari, M.; Movafagh, A.; Hashemi, M. Anticancer Activity of Curcumin on Human Breast Adenocarcinoma: Role of Mcl-1 Gene. Iran. J. Cancer Prev. 2015, 8(3), e2331. [CrossRef] [PubMed]

13. Shehzad, A.; Lee, J.; Lee, Y.S. Curcumin in various cancers. Biofactors 2013, 39(1), 56-68. [CrossRef] [PubMed]

14. Chendil, D.; Ranga, R.S.; Meigooni, D.; Sathishkumar, S.; Ahmed, M.M. Curcumin confers radiosensitizing effect in prostate cancer cell line PC-3. Oncogene 2004, 23, 1599-1607. [CrossRef] [PubMed]

15. Sandur, S.K.; Deorukhkar, A.; Pandey, M.K.; Pabón, A.M.; Shentu, S.; Guha, S.; Aggarwal, B.B.; Krishnan, S.; Krishnan, S. Curcumin modulates the radiosensitivity of colorectal cancer cells by suppressing constitutive and inducible NF-kappaB activity. Int. J. Radiat. Oncol. Biol. Phys. 2009, 75, 534-542. [CrossRef]

16. Qian, Y.; Ma, J.; Guo, X.; Sun, J.; Yu, Y.; Cao, B.; Zhang, L.; Ding, X.; Huang, J.; Shao, J.F. Curcumin enhances the radiosensitivity of U87 cells by inducing DUSP-2 Up-regulation. Cell Physiol. Biochem. 2015, 35, 1381-1393. [CrossRef]

17. Minafra, L.; Porcino, N.; Bravatà, V.; Gaglio, D.; Bonanomi, M.; Amore, E.; Cammarata, F.P.; Russo, G.; Militello, C.; Savoca, G.; et al. Radiosensitizing effect of Curcumin-loaded lipid nanoparticles in breast cancer cells. Nat. Scie. Rep. 2019, 9, 11134. [CrossRef]

18. Khafif, A.; Lev-Ari, S.; Vexler, A.; Barnea, I.; Starr, A.; Karaush, V.; Haif, S.; Ben-Yosef, R. Curcumin: A potential radio-enhancer in head and neck cancer. Laryngoscope 2009, 119, 2019-2026. [CrossRef]

19. Renaud, S.; De Lorgeril, M. Wine, alcohol, platelets, and the French paradox for coronary heart disease. Lancet 1992, 339, 1523-1526. [CrossRef]

20. Zhang, C.X.; Liu, Y.M.; Chen, K.L.; Chen, G. A comparative study of anti-aging properties and mechanism: Resveratrol and caloric restriction. Oncotarget 2017, 8, 65717-65729.

21. Ko, J.H.; Sethi, G.; Um, J.Y.; Shanmugam, M.K.; Arfuso, F.; Kumar, A.P.; Bishayee, A.; Ahn, K.S. The Role of Resveratrol in Cancer Therapy. Int. J. Mol. Sci. 2017, 18, 12. [CrossRef]

22. Salehi, B.; Mishra, A.P.; Nigam, M.; Sener, B.; Kilic, M.; Sharifi-Rad, M.; Fokou, P.V.T.; Martins, N.; Sharifi-Rad, J. Resveratrol: A Double-Edged Sword in Health Benefits. Biomedicines 2018, 9, 6. [CrossRef] [PubMed]

23. Mukherjee, S.; Dudley, J.I.; Das, D.K. Dose-dependency of resveratrol in providing health benefits. Dose Response 2010, 8(4), 478-500. [CrossRef] [PubMed]

24. Varoni, E.M.; Lo Faro, A.F.; Sharifi-Rad, J.; Iriti, M. Anticancer Molecular Mechanisms of Resveratrol. Front. Nutr. 2016, 3, 8. [CrossRef] [PubMed]

25. Johnson, G.E.; Ivanov, V.N.; Hei, T.K. Radiosensitization of melanoma cells through combined inhibition of protein regulators of cell survival. Apoptosis 2008, 13, 790-802. [CrossRef]

26. Luo, H.; Yang, A.; Schulte, B.A.; Wargovich, M.J.; Wang, G.Y. Resveratrol Induces Premature Senescence in Lung Cancer Cells via ROS-Mediated DNA Damage. PLoS ONE 2013, 8, e60065. [CrossRef]

27. Wang, L.; Long, L.; Wang, W.; Liang, Z. Resveratrol, a potential radiation sensitizer for glioma stem cells both in vitro and in vivo. J. Pharmacol. Sci. 2015, 129, 216-225. [CrossRef]

28. Khoei, S.; Shoja, M.; Mostaar, A.; Faeghi, F. Effects of resveratrol and methoxyamine on the radiosensitivity of iododeoxyuridine in U87MG glioblastoma cell line. Exp. Biol. Med. 2016, 241, 1229-1236. [CrossRef]

29. Baek, S.H.; Ko, J.H.; Lee, H.; Jung, J.; Kong, M.; Lee, J.W.; Lee, J.; Chinnathambi, A.; Zayed, M.E.; Alharbi, S.A.; et al. Resveratrol inhibits STAT3 signaling pathway through the induction of SOCS-1: Role in apoptosis induction and radiosensitization in head and neck tumor cells. Phytomedicine 2016, 23, 566-577. [CrossRef]

30. Chen, Y.A.; Lien, H.M.; Kao, M.C.; Lo, U.G.; Lin, L.C.; Lin, C.J.; Chang, S.J.; Chen, C.C.; Hsieh, J.T.; Lin, H.; et al. Sensitization of radioresistant prostate cancer cells by resveratrol isolated from arachis hypogaea stems. PLoS ONE 2017, 12, e0169204. [CrossRef] 
31. Tan, Y.; Wei, X.; Zhang, W.; Wang, X.; Wang, K.; Du, B.; Xiao, J. Resveratrol enhances the radiosensitivity of nasopharyngeal carcinoma cells by downregulating E2F1. Oncol. Rep. 2017, 37, 1833-1841. [CrossRef]

32. da Costa Araldi, I.C.; Bordin, F.P.R.; Cadoná, F.C.; Barbisan, F.; Azzolin, V.F.; Teixeira, C.F.; Baumhardt, T.; da Cruz, I.B.M.; Duarte, M.M.M.F.; Bauermann, L.F. The in vitro radiosensitizer potential of resveratrol on MCF-7 breast cancer cells. Chem. Biol. Interact. 2018, 282, 85-92. [CrossRef] [PubMed]

33. Tomé-Carneiro, J.; Gonzálvez, M.; Larrosa, M.; Yáñez-Gascón, M.J.; García-Almagro, F.J.; Ruiz-Ros, J.A.; Tomás-Barberán, F.A.; García-Conesa, M.T.; Espín, J.C. Grape resveratrol increases serum adiponectin and downregulates inflammatory genes in peripheral blood mononuclear cells: A triple-blind, placebo-controlled, one-year clinical trial in patients with stable coronary artery disease. Cardiovasc. Drugs Ther. 2013, 27(1), 37-48. [CrossRef] [PubMed]

34. Kupchan, S.M.; Doskotch, R.W.; Bollinger, P.; McPhail, A.T.; Sim, G.A.; Renauld, J.A.S. The Isolation and Structural Elucidation of a Novel Steroidal Tumor Inhibitor from Acnistus arborescens. J. Am. Chem. Soc. 1965, 87, 5805-5806. [CrossRef] [PubMed]

35. Shohat, B.; Gitter, S.; Abraham, A.; Lavie, D. Antitumor activity of withaferin A (NSC-101088). Cancer Chemother. Rep. 1967, 51, 271-276. [PubMed]

36. Lee, I.C.; Choi, B.Y. Withaferin-A-A natural anticancer agent with pleitropic mechanisms of action. Int. J. Mol. Sci. 2016, 17, 290. [CrossRef] [PubMed]

37. Devi, P.U. Withaferin A: A new radiosensitizer from the Indian medicinal plant Withania somnifera. Int. J. Radiat. Biol. 1996, 69, 193-197. [CrossRef]

38. Sharada, A.C.; Solomon, F.E.; Devi, P.U.; Udupa, N.; Srinivasan, K.K. Antitumor and radiosensitizing effects of withaferin A on mouse Ehrlich ascites carcinoma in vivo. Acta Oncol. 1996, 35, 95-100. [CrossRef]

39. Kamath, R.; Rao, B.S.S.; Devi, P.U. Response of a Mouse Fibrosarcoma to Withaferin A and Radiation. Pharm. Pharmacol. Commun. 1999, 5, 287-291. [CrossRef]

40. Devi, P.U.; Kamath, R.; Rao, B.S. Radiosensitization of a mouse melanoma by withaferin A: In vivo studies. Indian J. Exp. Biol. 2000, 38, 432-437.

41. Oh, J.H.; Lee, T.J.; Kim, S.H.; Choi, Y.H.; Lee, S.H.; Lee, J.M.; Kim, Y.H.; Park, J.W.; Kwon, T.K. Induction of apoptosis by withaferin A in human leukemia U937 cells through down-regulation of Akt phosphorylation. Apoptosis 2008, 13, 1494-1504. [CrossRef]

42. Yang, E.S.; Choi, M.J.; Kim, J.H.; Choi, K.S.; Kwon, T.K. Combination of withaferin A and X-ray irradiation enhances apoptosis in U937 cells. Toxicol. Vitr. 2011, 25, 1803-1810. [CrossRef] [PubMed]

43. Yang, E.S.; Choi, M.J.; Kim, J.H.; Choi, K.S.; Kwon, T.K. Withaferin A enhances radiation-induced apoptosis in Caki cells through induction of reactive oxygen species, Bcl-2 downregulation and Akt inhibition. Chem. Biol. Interact. 2011, 190, 9-15. [CrossRef] [PubMed]

44. Zhu, H.; Liu, X.W.; Cai, T.Y.; Cao, J.; Tu, C.X.; Lu, W.; He, Q.J.; Yang, B. Celastrol acts as a potent antimetastatic agent targeting beta1 integrin and inhibiting cell-extracellular matrix adhesion, in part via the p38 mitogen-activated protein kinase pathway. J. Pharmacol. Exp. Ther. 2010, 334, 489-499. [CrossRef] [PubMed]

45. Dai, Y.; DeSano, J.T.; Meng, Y.; Ji, Q.; Ljungman, M.; Lawrence, T.S.; Xu, L. Celastrol potentiates radiotherapy by impairment of DNA damage processing in human prostate cancer. Int. J. Radiat. Oncol. Biol. Phys. 2009, 74, 1217-1225. [CrossRef] [PubMed]

46. Bae, S. Enhancement of radiation sensitivity in lung cancer cells by celastrol is mediated by inhibition of Hsp90. Int. J. Mol. Med. 2011, 27, 441-446. [CrossRef] [PubMed]

47. Seo, H.R.; Seo, W.D.; Pyun, B.J.; Lee, B.W.; Jin, Y.B.; Park, K.H.; Seo, E.K.; Lee, Y.J.; Lee, Y.S. Radiosensitization by celastrol is mediated by modification of antioxidant thiol molecules. Chem. Biol. Interact. 2011, 193, $34-42$. [CrossRef]

48. Jun, H.Y.; Kim, T.H.; Choi, J.W.; Lee, Y.H.; Lee, K.K.; Yoon, K.H. Evaluation of connectivity map-discovered celastrol as a radiosensitizing agent in a murine lung carcinoma model: Feasibility study of diffusion-weighted magnetic resonance imaging. PLoS ONE 2017, 12, e0178204. [CrossRef]

49. Woźniak, Ł.; Skapska, S.; Marszałek, K. Ursolic Acid-A Pentacyclic Triterpenoid with a Wide Spectrum of Pharmacological Activities. Molecules 2015, 20, 20614-20641. [CrossRef]

50. Koh, S.J.; Tak, J.K.; Kim, S.T.; Nam, W.S.; Kim, S.Y.; Park, K.M.; Park, J.W. Sensitization of ionizing radiation-induced apoptosis by ursolic acid. Free Radic. Res. 2012, 46, 339-345. [CrossRef] 
51. Lee, Y.H.; Wang, E.; Kumar, N.; Glickman, R.D. Ursolic acid differentially modulates apoptosis in skin melanoma and retinal pigment epithelial cells exposed to UV-VIS broadband radiation. Apoptosis 2014, 19, 816-828. [CrossRef]

52. Yang, Y.; Jiang, M.; Hu, J.; Lv, X.; Yu, L.; Qian, X.; Liu, B. Enhancement of Radiation Effects by Ursolic Acid in BGC-823 Human Adenocarcinoma Gastric Cancer Cell Line. PLoS ONE 2015, 10, e0133169. [CrossRef] [PubMed]

53. Song, B.; Zhang, Q.; Yu, M.; Qi, X.; Wang, G.; Xiao, L.; Yi, Q.; Jin, W. Ursolic acid sensitizes radioresistant NSCLC cells expressing HIF-1 $\alpha$ through reducing endogenous GSH and inhibiting HIF-1 $\alpha$. Oncol. Lett. 2017, 2, 754-762. [CrossRef] [PubMed]

54. Chan, M.L.; Liang, J.W.; Hsu, L.C.; Chang, W.L.; Lee, S.S.; Guh, J.H. Zerumbone, a ginger sesquiterpene, induces apoptosis and autophagy in human hormone-refractory prostate cancers through tubulin binding and crosstalk between endoplasmic reticulum stress and mitochondrial insult. Naunyn Schmiedebergs Arch. Pharmacol. 2015, 388, 1223-1236. [CrossRef] [PubMed]

55. Fusi, F.; Durante, M.; Sgaragli, G.; Khanh, P.N.; Son, N.T.; Huong, T.T.; Cuong, N.M. In vitro vasoactivity of zerumbone from Zingiber zerumbet. Planta Med. 2015, 81, 298-304. [CrossRef]

56. Yob, N.J.; Joffry, S.M.; Affandi, M.M.; Teh, L.K.; Salleh, M.Z.; Zakaria, Z.A. Zingiber zerumbet (L.) Smith: A review of its ethnomedicinal, chemical, and pharmacological uses. Evid. Based Complement. Altern. Med. 2011, 2011, 543216. [CrossRef]

57. Sung, B.; Jhurani, S.; Ahn, K.S.; Mastuo, Y.; Yi, T.; Guha, S.; Liu, M.; Aggarwal, B.B. Zerumbone downregulates chemokine receptor CXCR4 expression leading to inhibition of CXCL12-induced invasion of breast and pancreatic tumor cells. Cancer Res. 2008, 68, 8938-8944. [CrossRef]

58. Murakami, A.; Tanaka, T.; Lee, J.Y.; Surh, Y.J.; Kim, H.W.; Kawabata, K.; Nakamura, Y.; Jiwajinda, S.; Ohigashi, H. Zerumbone, a sesquiterpene in subtropical ginger, suppresses skin tumor initiation and promotion stages in ICR mice. Int. J. Cancer 2004, 110, 481-490. [CrossRef]

59. Rahman, H.S.; Rasedee, A.; Yeap, S.K.; Othman, H.H.; Chartrand, M.S.; Namvar, F.; Abdul, A.B.; How, C.W. Biomedical properties of a natural dietary plant metabolite, zerumbone, in cancer therapy and chemoprevention trials. Biomed. Res. Int. 2017, 2014, 920742. [CrossRef]

60. Choi, S.H.; Lee, Y.J.; Seo, W.D.; Lee, H.J.; Nam, J.W.; Lee, Y.J.; Kim, J.; Seo, E.K.; Lee, Y.S. Altered cross-linking of HSP27 by zerumbone as a novel strategy for overcoming HSP27-mediated radioresistance. Int. J. Radiat. Oncol. Biol. Phys. 2011, 79, 1196-1205. [CrossRef]

61. Huang, G.C.; Chien, T.Y.; Chen, L.G.; Wang, C.C. Antitumor effects of zerumbone from Zingiber zerumbet in P-388D1 cells in vitro and in vivo. Planta Med. 2005, 71, 219-224. [CrossRef]

62. Chiang, M.F.; Chen, H.H.; Chi, C.W.; Sze, C.I.; Hsu, M.L.; Shieh, H.R.; Lin, C.P.; Tsai, J.T.; Chen, Y.J. Modulation of Sonic hedgehog signaling and WW domain containing oxidoreductase WOX1 expression enhances radiosensitivity of human glioblastoma cells. Exp. Biol. Med. 2015, 240, 392-399. [CrossRef] [PubMed]

63. Chiang, P.K.; Tsai, W.K.; Chen, M.; Lin, W.R.; Chow, Y.C.; Lee, C.C.; Hsu, J.M.; Chen, Y.J. Zerumbone Regulates DNA Repair Responding to Ionizing Radiation and Enhances Radiosensitivity of Human Prostatic Cancer Cells. Int. Cancer Ther. 2018, 17, 292-298. [CrossRef] [PubMed]

64. Deorukhkar, A.; Ahuja, N.; Mercado, A.L.; Diagaradjane, P.; Raju, U.; Patel, N.; Mohindra, P.; Diep, N.; Guha, S.; Krishnan, S. Zerumbone increases oxidative stress in a thiol-dependent ROS-independent manner to increase DNA damage and sensitize colorectal cancer cells to radiation. Cancer Med. 2015, 4, 278-292. [CrossRef] [PubMed]

65. Grunberger, D.; Banerjee, R.; Eisinger, K.; Oltz, E.M.; Efros, L.; Caldwell, M.; Estevez, V.; Nakanishi, K. Preferential cytotoxicity on tumor cells by caffeic acid phenethyl ester isolated from propolis. Experienita 1988, 44, 230-232. [CrossRef] [PubMed]

66. Cotgreave, I.A.; Gerdes, R.G. Recent trend in glutathione biochemistry-glutatione-protein interactions: A molecular link between oxidative stress and cell proliferation? Biochem. Biophys. Res. Commun. 1998, 242, 1-9. [CrossRef] [PubMed]

67. Kudugunti, S.K.; Vad, N.M.; Whiteside, A.J.; Naik, B.U.; Yusuf, M.A.; Srivenugopal, K.S.; Moridani, M.Y. Biochemical mechanism of caffeic acid phenylethyl ester (CAPE) selective toxicity towards melanoma cell lines. Chem. Biol. Interact. 2010, 188, 1-14. [CrossRef] 
68. Lee, Y.Y.; Kao, C.L.; Tsai, P.H.; Tsai, T.H.; Chiou, S.H.; Wu, W.F.; Ku, H.H.; Wong, T.T. Caffeic acid phenethyl ester preferentially enhanced radiosensitizing and increased oxidative stress in medulloblastoma cell line. Childs Nerv. Syst. 2008, 24, 987-994. [CrossRef]

69. Lin, Y.H.; Chiu, J.H.; Tseng, W.S.; Wong, T.T.; Chiou, S.H.; Yen, S.H. Antiproliferation and radiosensitization of caffeic acid phenethyl ester on human medulloblastoma cells. Cancer Chemother. Pharmacol. 2006, 57, 525-532. [CrossRef]

70. Chen, Y.J.; Liao, H.F.; Tsai, T.H.; Wang, S.Y.; Shiao, M.S. Caffeic Acid Phenethyl Ester Preferentially Sensitizes CT26 Colorectal Adenocarcinoma to Ionizing Radiation without affecting Bone Marrow Radioresponse. Int. J. Rad. Oncol. Biol. Phys. 2005, 63, 1252-1261. [CrossRef]

71. Khoram, N.M.; Bigdeli, B.; Nikoofar, A.; Goliaei, B. Caffeic Acid Phenethyl Ester Increases Radiosensitivity of Estrogen Receptor -Positive and -Negative Breast Cancer Cells by Prolonging Radiation-Induced DNA Damage. J. Breast Cancer 2016, 19, 18-25. [CrossRef]

72. Chen, M.F.; Wu, C.T.; Chen, Y.J.; Keng, P.C.; Chen, W.C. Cell killing and radiosensitization by caffeic acid phenethyl ester (CAPE) in lung cancer cells. J. Rad. Res. 2004, 45, 253-260. [CrossRef] [PubMed]

73. Chen, T.; Zheng, L.Y.; Xiao, W.; Gui, D.; Wang, X.; Wang, N. Emodin ameliorates high glucose induced-podocyte epithelial-mesenchymal transition in vitro and in vivo. Cell Physiol. Biochem. 2015, 35, 1425-1436. [CrossRef] [PubMed]

74. Li, L.; Tian, Y.; Yu, J.; Song, X.; Jia, R.; Cui, Q.; Tong, W.; Zou, Y.; Li, L.; Yin, L.; et al. iTRAQ-based quantitative proteomic analysis reveals multiple effects of Emodin to Haemophilus parasuis. J. Proteom. 2017, 166, $39-47$. [CrossRef] [PubMed]

75. Liu, Y.; Hou, H.X.; Li, D.R.; Cheng, D.H.; Qin, C.M.; Li, W. Enhancement effect of emodin on radiosensitivity of human nasopharyngeal carcinoma transplanted in nude mice. Chin. Pharm. J. 2010, 45, 1331-1334.

76. Dey, D.; Ray, R.; Hazra, B. Antitubercular and antibacterial activity of quinonoid natural products against multi-drug resistant clinical isolates. Phytother. Res. 2014, 28, 1014-1021. [CrossRef]

77. Shrimali, D.; Shanmugam, M.K.; Kumar, A.P.; Zhang, J.; Tan, B.K.; Ahn, K.S.; Sethi, G. Targeted abrogation of diverse signal transduction cascades by emodin for the treatment of inflammatory disorders and cancer. Cancer Lett. 2014, 341, 139-149. [CrossRef]

78. Gu, J.; Cui, C.F.; Yang, L.; Wang, L.; Jiang, X.H. Emodin inhibits colon cancer cell invasion and migration by suppressing epithelial mesenchymal transition via the Wnt/ $\beta$-catenin pathway. Oncol. Res. 2018, 27, 193-202. [CrossRef]

79. Hou, H.; Li, D.; Cheng, D.; Li, L.; Liu, Y.; Zhou, Y. Cellular Redox Status Regulates Emodin-Induced Radiosensitization of Nasopharyngeal Carcinoma Cells In Vitro and In Vivo. J. Pharm. 2013, 2013, 218297. [CrossRef]

80. Luo, J.; Yuan, Y.; Chang, P.; Li, D.; Liu, Z.; Qu, Y. Combination of aloe-emodin with radiation enhances radiation effects and improves differentiation in human cervical cancer cells. Mol. Med. Rep. 2014, 10, 731-736. [CrossRef]

81. Hwang, S.Y.; Heo, K.; Kim, J.S.; Im, J.W.; Lee, S.M.; Cho, M.; Kang, D.H.; Heo, J.; Lee, J.W.; Choi, C.W.; et al. Emodin attenuates radioresistance induced by hypoxia in HepG2 cells via the enhancement of PARP1 cleavage and inhibition of JMJD2B. Oncol. Rep. 2015, 33, 1691-1698. [CrossRef]

82. Miller, R.C.; Murley, J.S.; Rademaker, A.W.; Woloschak, G.E.; Li, J.J.; Weichselbaum, R.R.; Grdina, D.J. Very low doses of ionizing radiation and redox associated modifiers affect survivin-associated changes in radiationsensitivity. Free Rad. Biol. Med. 2016, 99, 110-119. [CrossRef] [PubMed]

83. Mo, Y.; Hou, H.; Li, D.; Liang, Y.; Chen, D.; Zhou, Y. Mitochondrial protein targets of radiosensitisation by 1,8-dihydroxy-3-acetyl-6-methyl-9,10 anthraquinone on nasopharyngeal carcinoma cells. Eur. J. Pharmacol. 2014, 738, 133-141. [CrossRef] [PubMed]

84. Bible, K.C.; Kaufmann, S.H. Cytotoxic synergy between flavopiridol (NSC 649890, L86-8275) and various antineoplastic agents: The importance of sequence of administration. Cancer Res. 1997, 57, 3375-3380. [PubMed]

85. Kaur, G.; Stetler-Stevenson, M.; Sebers, S.; Worland, P.; Sedlacek, H.; Myers, C.; Czech, J.; Naik, R.; Sausville, E. Growth inhibition with reversible cell cycle arrest of carcinoma cells by flavone L86-8275. J. Natl. Cancer Inst. 1992, 84, 1736-1740. [CrossRef] 
86. Byrd, J.C.; Shinn, C.; Waselenko, J.K.; Fuchs, E.J.; Lehman, T.A.; Nguyen, P.L.; Flinn, I.W.; Diehl, L.F.; Sausville, E.; Grever, M.R. Flavopiridol induces apoptosis in chronic lymphocytic leukemia cells via activation of caspase-3 without evidence of bcl-2 modulation or dependence on functional p53. Blood 2008, 92, 3804-3816. [CrossRef]

87. Patel, V.; Senderowicz, A.M.; Pinto, D.; Igishi, T.; Raffeld, M.; Quintanilla-Martinez, L.; Ensley, J.F.; Sausville, E.A.; Gutkind, J.S. Flavopiridol, a novel cyclin-dependent kinase inhibitor, suppresses the growth of head and neck squamous cell carcinomas by inducing apoptosis. J. Clin. Invest. 1998, 102, 1674-1681. [CrossRef]

88. Chen, R.; Keating, M.J.; Gandhi, V.; Plunkett, W. Transcription inhibition by flavopiridol: Mechanism of chronic lymphocytic leukemia cell death. Blood 2005, 106, 2513-2519. [CrossRef]

89. Melillo, G.; Sausville, E.A.; Cloud, K.; Lahusen, T.; Varsio, L.; Senderowicz, A.M. Flavopiridol, a protein kinase inhibitor, downregulates hypoxic induction of vascular endothelial growth factor expression in human monocytes. Cancer Res. 1999, 59, 5433-5437.

90. Motwani, M.; Delohery, T.M.; Schwartz, G.K. Sequential dependent enhancement of caspase activation and apoptosis by flavopiridol on paclitaxel-treated human gastric and breast cancer cells. Clin. Cancer Res. 1999, 5, 1876-1883.

91. Kim, J.C.; Saha, D.; Cao, Q.; Choy, H. Enhancement of radiation effects by combined docetaxel and flavopiridol treatment in lung cancer cells. Radiother. Oncol. 2004, 71, 213-221. [CrossRef]

92. Sato, S.; Kajiyama, Y.; Sugano, M.; Iwanuma, Y.; Tsurumaru, M. Flavopiridol as a radio-sensitizer for esophageal cancer cell lines. Dis. Esophagus. 2004, 17, 338-344. [CrossRef] [PubMed]

93. Yao, Y.; Shi, J.; Zhang, Z.; Zhang, F.; Ma, R.; Zhao, Y. The radiation-sensitizing effect of flavopiridol in the esophageal cancer cell line Eca109. Oncol. Lett. 2013, 5, 1872-1876. [CrossRef] [PubMed]

94. Raju, U.; Ariga, H.; Koto, M.; Lu, X.; Pickett, J.; Valdecanas, D.; Mason, K.A.; Milas, L. Improvement of esophageal adenocarcinoma cell and xenograft responses to radiation by targeting cyclin-dependent kinases. Radiother. Oncol. 2006, 80, 185-191. [CrossRef] [PubMed]

95. Hara, T.; Omura-Minamisawa, M.; Kang, Y.; Cheng, C.; Inoue, T. Flavopiridol potentiates the cytotoxic effects of radiation in radioresistant tumor cells in which p53 is mutated or Bcl-2 is overexpressed. Int. J. Radiat. Oncol. Biol. Phys. 2008, 71, 1485-1495. [CrossRef]

96. Lee, J.M.; Bernstein, A. p53 mutations increase resistance to ionizing radiation. Proc. Natl. Acad. Sci. USA 1993, 90, 5742-5746. [CrossRef]

97. Gilbert, M.; Knox, S. Influence of Bcl-2 overexpression on $\mathrm{Na}^{+} / \mathrm{K}^{(+)}$-ATPase pump activity: Correlation with radiation-induced programmed cell death. J. Cell Physiol. 1997, 171, 299-304. [CrossRef]

98. Khanna, K.K.; Jackson, S.P. DNA double-strand breaks: Signaling, repair and the cancer connection. Nat. Genet. 2001, 27, 247-254. [CrossRef]

99. Daboussi, F.; Dumay, A.; Delacôte, F.; Lopez, B.S. DNA double-strand break repair signalling: The case of RAD51 post-translational regulation. Cell Signal. 2002, 14, 969-975. [CrossRef]

100. Saintigny, Y.; Dumay, A.; Lambert, S.; Lopez, B.S. A novel role for the Bcl-2 protein family: Specific suppression of the RAD51 recombination pathway. EMBO J. 2001, 20, 2596-2607. [CrossRef]

101. Newcomb, E.W.; Ali, M.A.; Schnee, T.; Lan, L.; Lukyanov, Y.; Fowkes, M.; Miller, D.C.; Zagzag, D. Flavopiridol downregulates hypoxia-mediated hypoxia-inducible factor-1a expression in human glioma cells by a proteasome-independent pathway: Implications for in vivo therapy. Neuro-Oncol. 2005, 7, 225-235. [CrossRef]

102. Newcomb, E.W.; Lymberis, S.C.; Lukyanov, Y.; Shao, Y.; Schnee, T.; Devitt, M.; Rosenstein, B.S.; Zagzag, D.; Formenti, S.C. Radiation sensitivity of GL261 murine glioma model and enhanced radiation response by flavopiridol. Cell Cycle 2006, 5, 93-99. [CrossRef] [PubMed]

103. Jin, S.; Weaver, D.T. Double-strand break repair by Ku70 requires heterodimerization with Ku80 and DNA binding functions. EMBO J. 1997, 16, 6874-6885. [CrossRef] [PubMed]

104. Sinclair, W.K.; Mortan, R.A. X-ray sensitivity during the cell generation cycle of cultured Chinese hamster cells. Radiat. Res. 1966, 29, 450-474. [CrossRef] [PubMed]

105. Sedlacek, H.H. Mechanisms of action of flavopiridol. Crit Rev. Oncol. Hematol. 2001, 38, 139-170. [CrossRef]

106. Weinberg, R.A. The retinoblastoma protein and cell cycle control. Cell 1995, 81, 323-330. [CrossRef]

107. Peng, J.; Zhu, Y.; Milton, J.T.; Price, D.H. Identification of multiple cyclin subunits of human P-TEFb. Genes Dev. 1998, 12, 755-762. [CrossRef] [PubMed] 
108. Fu, T.; Peng, J.; Lee, G.; Price, D.H.; Flores, O. Cyclin K functions as a CDK9 regulatory subunit and participates in RNA polymerase II transcription. J. Biol. Chem. 1999, 274, 34527-34530. [CrossRef]

109. Raju, U.; Nakata, E.; Mason, K.A.; Ang, K.K.; Milas, L. Flavopiridol, a cyclin dependent kinase inhibitor, enhances radiosensitivity of ovarian carcinoma cells. Cancer Res. 2003, 63, 3263-3326.

110. Kim, S.; Wu, H.G.; Shin, J.H.; Park, H.J.; Kim, I.A.; Kim, I.H. Enhancement of radiation effects by flavopiridol in uterine cervix cancer cells. Cancer Res. Treat. 2005, 37, 191-195. [CrossRef]

111. Camphausen, K.; Brady, K.J.; Burgan, W.E.; Cerra, M.A.; Russell, J.S.; Bull, E.E.; Tofilon, P.J. Flavopiridol enhances human tumor cell radiosensitivity and prolongs expression of gammaH2AX foci. Mol. Cancer Ther. 2004, 3, 409-416.

112. McAleer, M.F.; Duffy, K.T.; Davidson, W.R.; Kari, G.; Dicker, A.P.; Rodeck, U.; Wickstrom, E. Antisense inhibition of cyclin D1 expression is equivalent to flavopiridol for radiosensitization of zebrafish embryos. Int. J. Radiat. Oncol. Biol. Phys. 2006, 66, 546-551. [CrossRef] [PubMed]

113. Zhang, Y.; Li, X.; Zou, D.; Liu, W.; Yang, J.; Zhu, N.; Huo, L.; Wang, M.; Hong, J.; Wu, P.; et al. Treatment of type 2 diabetes and dyslipidemia with the natural plant alkaloid berberine. J. Clin. Endocrinol. Metab. 2008, 93, 2559-2565. [CrossRef] [PubMed]

114. Yin, J.; Xing, H.; Ye, J. Efficacy of berberine in patients with type 2 diabetes mellitus. Metabolism 2008, 57, 712-717. [CrossRef] [PubMed]

115. Kong, W.; Wei, J.; Abidi, P.; Lin, M.; Inaba, S.; Li, C.; Wang, Y.; Wang, Z.; Si, S.; Pan, H. Berberine is a novel cholesterol-lowering drug working through a unique mechanism distinct from statins. Nat. Med. 2004, 10, 1344-1351. [CrossRef] [PubMed]

116. Sanders, M.M.; Liu, A.A.; Li, T.K.; Wu, H.Y.; Desai, S.D.; Mao, Y.; Rubin, E.H.; LaVoie, E.J.; Makhey, D.; Liu, L.F. Selective cytotoxicity of topoisomerase-directed protoberberines against glioblastoma cells. Biochem. Pharmacol. 1998, 56, 1157-1166. [CrossRef]

117. Lin, C.C.; Yang, J.S.; Chen, J.T.; Fan, S.; Yu, F.S.; Yang, J.L.; Lu, C.C.; Kao, M.C.; Huang, A.C.; Lu, H.F. Berberine induces apoptosis in human HSC-3 oral cancer cells via simultaneous activation of the death receptor-mediated and mitochondrial pathway. Anticancer Res. 2007, 27, 3371-3378.

118. Hwang, J.M.; Kuo, H.C.; Tseng, T.H.; Liu, J.Y.; Chu, C.Y. Berberine induces apoptosis through a mitochondria/caspases pathway in human hepatoma cells. Arch. Toxicol. 2006, 80, 62-73. [CrossRef]

119. Lin, J.P.; Yang, J.S.; Lee, J.H.; Hsieh, W.T.; Chung, J.G. Berberine induces cell cycle arrest and apoptosis in human gastric carcinoma SNU-5 cell line. World J. Gastroenterol. 2006, 12, 21-28. [CrossRef]

120. Mantena, S.K.; Sharma, S.D.; Katiyar, S.K. Berberine, a natural product, induces G1-phase cell cycle arrest and caspase-3-dependent apoptosis in human prostate carcinoma cells. Mol. Cancer Ther. 2006, 5, $296-308$. [CrossRef]

121. Lin, C.C.; Lin, S.Y.; Chung, J.G.; Lin, J.P.; Chen, G.W.; Kao, S.T. Down-regulation of cyclin B1 and up-regulation of Wee1 by berberine promotes entry of leukemia cells into the G2/M-phase of the cell cycle. Anticancer Res. 2006, 26, 1097-1104.

122. Liu, Z.; Liu, Q.; Xu, B.; Wu, J.; Guo, C.; Zhu, F.; Yang, Q.; Gao, G.; Gong, Y.; Shao, C. Berberine induces p53-dependent cell cycle arrest and apoptosis of human osteosarcoma cells by inflicting DNA damage. Mutat. Res. 2009, 662, 75-83. [CrossRef] [PubMed]

123. Peng, P.L.; Kuo, W.H.; Tseng, H.C.; Chou, F.P. Synergistic tumor-killing effect of radiation and berberine combined treatment in lung cancer: The contribution of autophagic cell death. Int. J. Radiat. Oncol. Biol. Phys. 2008, 70, 529-542. [CrossRef] [PubMed]

124. Liu, Q.; Jiang, H.; Liu, Z.; Wang, Y.; Zhao, M.; Hao, C.; Feng, S.; Guo, H.; Xu, B.; Yang, Q.; et al. Berberine radiosensitizes human esophageal cancer cells by downregulating homologous recombination repair protein RAD51. PLoS ONE 2011, 6, e23427. [CrossRef] [PubMed]

125. Moeller, B.J.; Dewhirst, M.W. HIF-1 and tumour radiosensitivity. Br. J. Cancer 2006, 95, 1-5. [CrossRef] [PubMed]

126. Semenza, G.L. Hypoxia-inducible factors: Mediators of cancer progression and targets for cancer therapy. Trends Pharmacol. Sci. 2012, 33, 207-214. [CrossRef] [PubMed]

127. Yang, X.; Yang, B.; Cai, J.; Zhang, C.; Zhang, Q.; Xu, L.; Qin, Q.; Zhu, H.; Ma, J.; Tao, G.; et al. Berberine enhances radiosensitivity of esophageal squamous cancer by targeting HIF- $1 \alpha$ in vitro and in vivo. Cancer Biol. Ther. 2013, 14, 1068-1073. [CrossRef] 
128. Zhang, Q.; Zhang, C.; Yang, X.; Yang, B.; Wang, J.; Kang, Y.; Wang, Z.; Li, D.; Huang, G.; Ma, Z.; et al. Berberine inhibits the expression of hypoxia induction factor-1alpha and increases the radiosensitivity of prostate cancer. Diagn. Pathol. 2014, 9, 98. [CrossRef]

129. Zhang, C.; Yang, X.; Zhang, Q.; Yang, B.; Xu, L.; Qin, Q.; Zhu, H.; Liu, J.; Cai, J.; Tao, G.; et al. Berberine radiosensitizes human nasopharyngeal carcinoma by suppressing hypoxia-inducible factor-1 $\alpha$ expression. Acta Otolaryngol. 2014, 134, 185-192. [CrossRef]

130. Rosser, C.J.; Tanaka, M.; Pisters, L.L.; Tanaka, N.; Levy, L.B.; Hoover, D.C.; Grossman, H.B.; McDonnell, T.J.; Kuban, D.A.; Meyn, R.E. Adenoviral-mediated PTEN transgene expression sensitizes Bcl-2-expressing prostate cancer cells to radiation. Cancer Gene Ther. 2004, 11, 273-279. [CrossRef]

131. Szotowski, B.; Antoniak, S.; Goldin-Lang, P.; Tran, Q.V.; Pels, K.; Rosenthal, P.; Bogdanov, V.Y.; Borchert, H.H.; Schultheiss, H.P.; Rauch, U. Antioxidative treatment inhibits the release of thrombogenic tissue factor from irradiation- and cytokine-induced endothelial cells. Cardiovasc. Res. 2007, 73, 806-812. [CrossRef]

132. Bohnke, A.; Westphal, F.; Schmidt, A.; El-Awady, R.A.; Dahm-Daphi, J. Role of p53 mutations, protein function and DNA damage for the radiosensitivity of human tumor cells. Int. J. Radiat. Biol. 2004, 80, 53-63. [CrossRef] [PubMed]

133. Zhang, Y.; Chen, F. Reactive oxygen species (ROS), troublemakers between nuclear factor-kappaB (NF-kappaB) and c-Jun $\mathrm{NH}^{(2)-}$ terminal kinase (JNK). Cancer Res. 2004, 64, 1902-1905. [CrossRef] [PubMed]

134. Hur, J.M.; Kim, D. Berberine inhibited radioresistant effects and enhanced antitumor effects in the irradiated-human prostate cancer cells. Toxicol. Res. 2010, 26, 109-115. [CrossRef] [PubMed]

135. Kim, W.Y.; Jang, J.Y.; Jeon, Y.K.; Chung, D.H.; Kim, Y.G.; Kim, C.W. Syntenin increases the invasiveness of small cell lung cancer cells by activating p38, AKT, focal adhesion kinase and SP1. Exp. Mol. Med. 2014, 46, e90. [CrossRef]

136. Kong, L.M.; Liao, C.G.; Zhang, Y.; Xu, J.; Li, Y.; Huang, W.; Zhang, Y.; Bian, H.; Chen, Z.N. A regulatory loop involving miR-22, Sp1, and c-Myc modulates CD147 expression in breast cancer invasion and metastasis. Cancer Res. 2014, 74, 3764-3778. [CrossRef] [PubMed]

137. Zhao, J.; Ye, W.; Wu, J.; Liu, L.; Yang, L.; Gao, L.; Chen, B.; Zhang, F.; Yang, H.; Li, Y. Sp1-CD147 positive feedback loop promotes the invasion ability of ovarian cancer. Oncol. Rep. 2015, 34, 67-76. [CrossRef] [PubMed]

138. Wang, J.; Kang, M.; Qin, Y.T.; Wei, Z.X.; Xiao, J.J.; Wang, R.S. Sp1 is over-expressed in nasopharyngeal cancer and is a poor prognostic indicator for patients receiving radiotherapy. Int. J. Clin. Exp. Pathol. 2015, 8, 6936-6943.

139. Wang, J.; Kang, M.; Wen, Q.; Qin, Y.T.; Wei, Z.X.; Xiao, J.J.; Wang, R.S. Berberine sensitizes nasopharyngeal carcinoma cells to radiation through inhibition of Sp1 and EMT. Oncol. Rep. 2017, 37, 2425-2432. [CrossRef]

140. Wang, J.; Liu, Q.; Yang, Q. Radiosensitization effects of berberine on human breast cancer cells. Int. J. Mol. Med. 2012, 30, 1166-1172. [CrossRef]

141. Uifălean, A.; Schneider, S.; Ionescu, C.; Lalk, M.; Iuga, C.A. Soy Isoflavones and Breast Cancer Cell Lines: Molecular Mechanisms and Future Perspectives. Molecules 2015, 21, E13. [CrossRef]

142. Spagnuolo, C.; Russo, G.L.; Orhan, I.E.; Habtemariam, S.; Daglia, M.; Sureda, A.; Nabavi, S.F.; Devi, K.P.; Loizzo, M.R.; Tundis, R.; et al. Genistein and Cancer: Current Status, Challenges, and Future Directions. Adv. Nutr. 2015, 6, 408-419. [CrossRef] [PubMed]

143. Banerjee, S.; Li, Y.; Wang, Z.; Sarkar, F.H. Multi-targeted therapy of cancer by genistein. Cancer Lett. 2008, 269, 226-242. [CrossRef] [PubMed]

144. Shi, Y. Mechanisms of caspase activation and inhibition during apoptosis. Mol. Cell 2002, 9, 459-470. [CrossRef]

145. Altieri, D.C. Validating survivin as a cancer therapeutic target. Nat. Rev. Cancer 2003, 3, 46-54. [CrossRef]

146. Bao, R.; Connolly, D.C.; Murphy, M.; Green, J.; Weinstein, J.K.; Pisarcik, D.A.; Hamilton, T.C. Activation of cancer-specific gene expression by the survivin promoter. J. Natl. Cancer Inst. 2002, 94, 522-528. [CrossRef]

147. Rödel, F.; Hoffmann, J.; Distel, L.; Herrmann, M.; Noisternig, T.; Papadopoulos, T.; Sauer, R.; Rödel, C. Survivin as a radioresistance factor, and prognostic and therapeutic target for radiotherapy in rectal cancer. Cancer Res. 2005, 65, 4881-4887. [CrossRef]

148. Zhang, B.; Liu, J.Y.; Pan, J.S.; Han, S.P.; Yin, X.X.; Wang, B.; Hu, G. Combined treatment of ionizing radiation with genistein on cervical cancer HeLa cells. J. Pharmacol. Sci. 2006, 102, 129-135. [CrossRef] 
149. Wang, S.Y.; Yang, K.W.; Hsu, Y.T.; Chang, C.L.; Yang, Y.C. The differential inhibitory effects of genistein on the growth of cervical cancer cells in vitro. Neoplasma 2001, 48, 227-233.

150. Yashar, C.M.; Spanos, W.J.; Taylor, D.D.; Gercel-Taylor, C. Potentiation of the radiation effect with genistein in cervical cancer cells. Gynecol. Oncol. 2005, 99, 199-205. [CrossRef]

151. Shin, J.I.; Shim, J.H.; Kim, K.H.; Choi, H.S.; Kim, J.W.; Lee, H.G.; Kim, B.Y.; Park, S.N.; Park, O.J.; Yoon, D.Y. Sensitization of the apoptotic effect of gamma-irradiation in genistein-pretreated CaSki cervical cancer cells. J. Microbiol. Biotechnol. 2008, 18, 523-531.

152. Liu, X.; Sun, C.; Jin, X.; Li, P.; Ye, F.; Zhao, T.; Gong, L.; Li, Q. Genistein enhances the radiosensitivity of breast cancer cells via $\mathrm{G}_{2} / \mathrm{M}$ cell cycle arrest and apoptosis. Molecules 2013, 18, 13200-13217. [CrossRef] [PubMed]

153. Lu, S.C. Glutathione synthesis. Biochim. Biophys. Acta. 2013, 1830, 3143-3153. [CrossRef] [PubMed]

154. Majid, S.; Dar, A.A.; Shahryari, V.; Hirata, H.; Ahmad, A.; Saini, S.; Tanaka, Y.; Dahiya, A.V.; Dahiya, R. Genistein reverses hypermethylation and induces active histone modifications in tumor suppressor gene B-cell translocation gene 3 in prostate cancer. Cancer 2010, 116, 66-76. [CrossRef] [PubMed]

155. Xie, Q.; Bai, Q.; Zou, L.Y.; Zhang, Q.Y.; Zhou, Y.; Chang, H.; Yi, L.; Zhu, J.D.; Mi, M.T. Genistein Inhibits DNA Methylation and Increases Expression of Tumor Suppressor Genes in Human Breast Cancer Cells. Gen. Chrom. Cancer 2014, 53, 422-431. [CrossRef] [PubMed]

156. Baird, L.; Llères, D.; Swift, S.; Dinkova-Kostova, A.T. Regulatory flexibility in the Nrf2-mediated stress response is conferred by conformational cycling of the Keap1-Nrf2 protein complex. Proc. Natl. Acad. Sci. USA 2013, 110, 15259-15264. [CrossRef]

157. Cho, H.Y.; Reddy, S.P.; Debiase, A.; Yamamoto, M.; Kleeberger, S.R. Gene expression profiling of NRF2-mediated protection against oxidative injury. Free Radic. Biol. Med. 2005, 38, 325-343. [CrossRef]

158. Liu, X.; Sun, C.; Liu, B.; Jin, X.; Li, P.; Zheng, X.; Zhao, T.; Li, F.; Li, Q. Genistein mediates the selective radiosensitizing effect in NSCLC A549 cells via inhibiting methylation of the keap1 gene promoter region. Oncotarget 2016, 7, 27267-27279. [CrossRef]

159. You, S.; Li, R.; Parco, D.; Xie, M.; Sica, G.L.; Cao, Y.; Xiao, Z.Q.; Deng, X. Disruption of STAT3 by niclosamide reverses radioresistance of human lung cancer. Mol. Cancer Ther. 2014, 3, 606-616. [CrossRef]

160. Pattingre, S.; Tassa, A.; Qu, X.; Garuti, R.; Liang, X.H.; Mizushima, N.; Packer, M.; Schneider, M.D.; Levine, B. Bcl-2 antiapoptotic proteins inhibit Beclin 1-dependent autophagy. Cell 2005, 122, 927-939. [CrossRef]

161. Du, Y.; Ji, X. Bcl-2 down-regulation by small interfering RNA induces Beclin1-dependent autophagy in human SGC-7901 cells. Cell Biol. Internat. 2014, 38, 1155-1162. [CrossRef]

162. Zhang, Z.; Jin, F.; Lian, X.; Li, M.; Wang, G.; Lan, B.; He, H.; Liu, G.D.; Wu, Y.; Sun, G.; et al. Genistein promotes ionizing radiation-induced cell death by reducing cytoplasmic Bcl-xL levels in non-small cell lung cancer. Sci. Rep. 2018, 8, 328. [CrossRef] [PubMed]

163. Kieliszek, M.; Lipinski, B.; Błażejak, S. Application of Sodium Selenite in the Prevention and Treatment of Cancers. Cells 2017, 6, 39. [CrossRef] [PubMed]

164. Kieliszek, M.; Lipinski, B. Pathophysiological significance of protein hydrophobic interactions: An emerging hypothesis. Med. Hypotheses 2018, 110, 15-22. [CrossRef] [PubMed]

165. Schueller, P.; Puettmann, S.; Micke, O.; Volker, S.; Schaefer, U.; Willich, N. Selenium Influences the Radiation Sensitivity of C6 Rat Glioma Cells. Anticancer Res. 2004, 24, 2913-2918. [PubMed]

166. Chen, F.; Hong Zhang, X.; Dan Hu, X.; Dang Liu, P.; Qian Zhang, H. The effects of combined selenium nanoparticles and radiation therapy on breast cancer cells in vitro. Artif. Cells Nanomed Biotechnol. 2018, 46(5), 937-948. [CrossRef]

167. Liu, T.; Shi, C.; Duan, L.; Zhang, Z.; Luo, L.; Goel, S.; Cai, W.; Chen, T. A highly hemocompatible erythrocyte membrane-coated ultrasmall selenium nanosystem for simultaneous cancer radiosensitization and precise antiangiogenesis. J. Mater. Chem. B 2018, 6(29), 4756-4764. [CrossRef]

168. Holsti, L.R. Development of clinical radiotherapy since 1896. Acta Oncol. 1995, 34, 995-1003. [CrossRef]

169. Alberti, C. Organ-confined prostate carcinoma radiation brachytherapy compared with external either photon- or hadron-beam radiation therapy. Just a short up-to-date. Eur. Rev. Med. Pharmacol. Sci. 2011, 15, 769-774. 
170. Cirrone, G.A.P.; Margarone, D.; Maggiore, M.; Anzalone, A.; Borghesi, M.; Bijan Jia, S.; Bulanov, S.S.; Bulanov, S.; Carpinelli, M.; Cavallaro, S.; et al. ELIMED: A new hadron therapy concept based on laser driven ion beams. Laser Acceleration of Electrons, Protons, and Ions II and Medical Applications of Laser-Generated Beams of Particles II and Harnessing Relativistic Plasma Waves III. Proc. SPIE Int. Soc. Opt. Eng. 2013, 8779. [CrossRef]

171. Islam, M.T. Radiation interactions with biological systems. Int. J. Radiat Biol. 2017, 93, 487-493. [CrossRef]

172. Das, L.; Bhaumik, E.; Raychaudhuri, U.; Chakraborty, R. Role of nutraceuticals in human health. J. Food Sci. Technol. 2012, 49, 73-183. [CrossRef] [PubMed]

173. Reed, D.; Raina, K.; Agarwal, R. Nutraceuticals in prostate cancer therapeutic strategies and their neo-adjuvant use in diverse populations. NPJ Precis. Oncol. 2018, 2, 15. [CrossRef] [PubMed]

174. Malfa, G.A.; Tomasello, B.; Acquaviva, R.; Genovese, C.; La Mantia, A.; Cammarata, F.P.; Ragusa, M.; Renis, M.; Di Giacomo, C. Betula etnensis Raf. (Betulaceae) Extract Induced HO-1 Expression and Ferroptosis Cell Death in Human Colon Cancer Cells. Int. J. Mol. Sci. 2019, 3, 2723. [CrossRef] [PubMed]

(C) 2019 by the authors. Licensee MDPI, Basel, Switzerland. This article is an open access article distributed under the terms and conditions of the Creative Commons Attribution (CC BY) license (http://creativecommons.org/licenses/by/4.0/). 